\title{
Passive Permeate-Side-Heated Solar Thermal Membrane Distillation: Extracting Potable Water from Seawater, Surface Water, and Municipal Wastewater at High Single-Stage Solar Efficiencies
}

\author{
Rahamat Ullah Tanvir ${ }^{\mathrm{a}, \dagger}$, Shahin Ahmed Sujon ${ }^{\mathrm{a}}$, and Peng Yi ${ }^{\mathrm{a}}{ }^{\text {* }}$ \\ a Department of Civil, Environmental and Geomatics Engineering, \\ Florida Atlantic University, Boca Raton, Florida, 33431, USA \\ ${ }^{\dagger}$ Current Address: Department of Civil and Environmental Engineering, University of Missouri, \\ Columbia, Missouri, 65211, USA \\ * Corresponding Author: Peng Yi, E-mail: pyi@fau.edu, Phone: (561)-297-2808
}




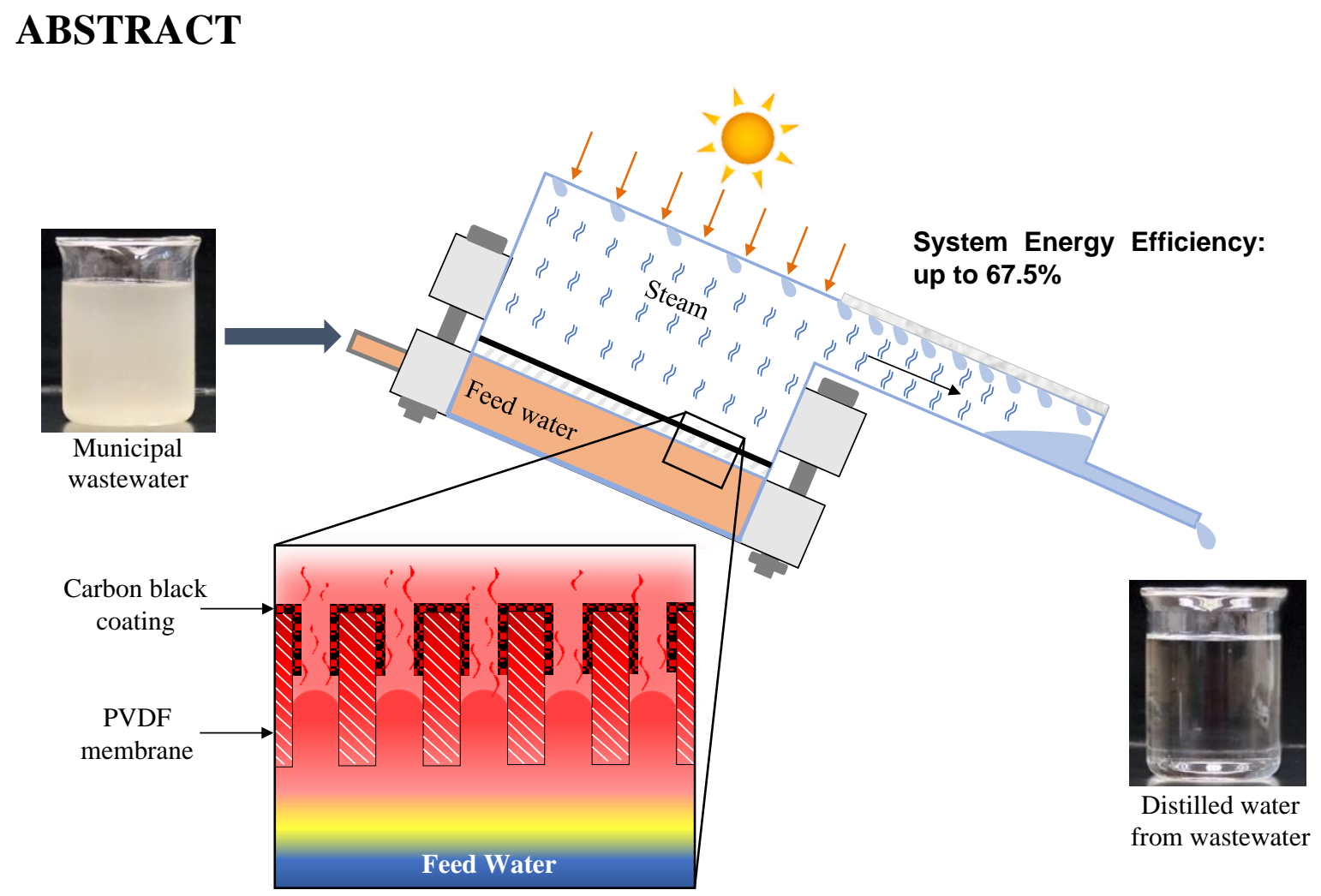

Globally, hundreds of millions of people still drink untreated surface water due to the lack of even a basic drinking water service, and urgently need economical off-grid water treatment devices. A passive, single-stage, permeate-side-heated solar thermal membrane distillation system is developed for extracting potable water from seawater, surface water, and municipal wastewater. The carbon black-coated permeate side of $0.45 \mu \mathrm{m}$ PVDF membrane absorbs solar radiation and evaporates the feed water within the pores of the membrane. Under natural sunlight, the distillate flux was $8.56 \mathrm{~kg} /\left(\mathrm{m}^{2} \cdot\right.$ day $)$ at an average daytime irradiance of $652 \mathrm{~W} / \mathrm{m}^{2}$, equivalent to the system energy efficiency of $67.5 \%$, the highest so far for single-stage solar distillation under natural sunlight. This system removed all the heterotrophic bacteria, $99.9 \%$ turbidity, and $99.6 \%$ chemical oxygen demand (COD) from wastewater, and reduced electrical conductivity by $99.9 \%$ from seawater, during the first 8 hours of operation under simulated sunlight $\left(1800 \mathrm{~W} / \mathrm{m}^{2}\right)$. The operation continued for 32,18, and 10 days on average for seawater, canal water, and wastewater, respectively, until the feed water penetrated the membrane. Throughout long-term experiments, distillate had decreasing flux within $0.98-1.55 \mathrm{~kg} /\left(\mathrm{m}^{2} \cdot \mathrm{h}\right)$, steady $\mathrm{pH}$ of $7.2-7.9$, steady turbidity of 0.09-0.21 NTU, steady electrical conductivity within $0.003-0.451 \mathrm{mS} / \mathrm{cm}$, and increasing COD within 1.9-9.2 mg/L regardless of the type of feed water. Comprehensive water quality tests show 
that the distillate extracted from all types of feed water meets U.S. drinking water standards for total coliform, 22 heavy metals and minerals, 7 anions, 5 physical factors, and 50 volatile organic compounds, and will be safe to drink in real-world applications.

KEYWORDS: Distributed water purification, Wastewater distillation, Desalination, Renewable energy, Interfacial heating

\section{INTRODUCTION}

Drinking water is one of the essential physiological human needs. However, each year, four billion people around the world face water crisis for at least a month, with half a billion people facing severe water scarcity all year round. ${ }^{1}$ People suffering the most are the rural dwellers in undeveloped areas. ${ }^{2-3}$ They often have to drink untreated turbid raw water due to lack of proper resources and infrastructure. Also, short-term drinking water scarcity is likely to occur during the post-natural disaster period as well. For instance, many places in New Orleans area did not have clean water for 2 to 8 weeks after the catastrophic Hurricane Katrina in 2005. ${ }^{4}$ After Hurricane Maria hit Puerto Rico in 2017, 93\% of the people lost power, and almost half of the population ( 1.6 million) had no tap water for more than two weeks. ${ }^{5}$ During that time, many people were isolated and resorted to polluted water sources for drinking water in spite of the supply of bottled water from Federal Emergency Management Agency (FEMA). ${ }^{6}$ Therefore, economical water purification systems requiring no electrical power are critical for the survival of those people living in off-grid or post-disaster areas. Since most areas facing water scarcity often have intense solar radiation, solar thermal water evaporation or distillation-condensation technology is one promising option, also because theoretically, it can remove all the non-volatile solutes, suspending particles, and microorganisms.

In recent years, interfacial solar heating technologies have been developed with great popularity for efficient water evaporation. Unlike conventional solar stills in which the black inner surface of the feed water container absorbs the solar thermal energy and heats the entire volume of feed water, interfacial heating technologies directly heat water molecules at the air-water interface and thus reduce the heat dissipation to the bulk water and the subsequent heat loss to the outer environment. ${ }^{7-12}$ Technically, the enhancement of energy efficiency of water evaporation $\left(\eta_{\text {evp }}\right)$ was achieved mostly through interfacial heating floats, namely, by floating solar radiation 
absorbing materials on the surface of water, in some cases with a thermal insulation layer between the solar absorber and the water surface, and in some cases with wick materials for drawing the feed water from underneath. Examples are $\mathrm{Fe}_{3} \mathrm{O}_{4} / \mathrm{C}$ particles $\left(\eta_{\text {evp }}=115 \%\right.$ under $\left.1.4 \mathrm{~kW} / \mathrm{m}^{2}\right),{ }^{13}$ aluminum nanoparticle (NP)-coated aluminum oxide nanoporous membrane $\left(\eta_{\mathrm{evp}}=88.4 \%\right.$ under 4 sun; 1 sun $\left.=1 \mathrm{~kW} / \mathrm{m}^{2}\right),{ }^{14} 1 \mathrm{~cm}$-thick $66 \%$ porous hydrophilic wood with a carbonized top surface $\left(\eta_{\mathrm{evp}}=86.7 \%\right.$ under $\left.10 \mathrm{sun}\right),{ }^{15}$ hydrophilic graphene oxide-based aerogel $\left(\eta_{\mathrm{evp}}=83 \%\right.$ under 1 sun), ${ }^{16}$ paper-based graphene oxide placed on cellulose-wrapped polystyrene foam ( $\eta_{\mathrm{evp}}=80 \%$ under 1 sun $),{ }^{17}$ hydrophilic CuS/collodion microporous membrane ( $\eta_{\text {evp }}=68.6 \%$ under 1 sun $),{ }^{18}$ hydrophilic graphite-carbon foam double layer ( $\eta_{\mathrm{evp}}=64 \%$ under 1 sun $),{ }^{8}$ hydrophilic CuS NPscoated $74 \mu \mathrm{m}$ polyethylene membrane $\left(\eta_{\mathrm{evp}}=63.9 \%\right.$ under $\left.1 \mathrm{sun}\right),{ }^{19}$ hydrophobic polypyrrolecoated stainless steel mesh $\left(\eta_{\mathrm{evp}}=58 \%\right.$ under 1 sun $),{ }^{20}$ etc.

Despite the success of interfacial heating float in numerous beaker evaporation tests, only a few groups developed their concepts into water evaporation-condensation systems and quantified the system energy efficiency ( $\eta_{\text {sys }}$ ) in producing distilled water using solar thermal energy. A system using floating polystyrene bars covered, wrapped, and connected by water-wicking hydrophilic cellulose fabric, produced $2.5 \mathrm{~L} /\left(\mathrm{m}^{2} \cdot \mathrm{d}\right)$ during a sunny day $\left(7 \mathrm{kWh} /\left(\mathrm{m}^{2} \cdot \mathrm{d}\right)\right)$, or $\eta_{\mathrm{sys}}=$ $24 \% .{ }^{21}$ Another system using floating carbon nanospheres-incorporated polyvinyl alcohol sponge achieved a distillate flux of $0.62 \mathrm{~kg} /\left(\mathrm{m}^{2} \cdot \mathrm{h}\right)$ under one sun, corresponding to $\eta_{\mathrm{sys}}=42 \%{ }^{22}$

The concept of interfacial heating was used in direct contact membrane distillation (MD) by two pioneering groups a few years ago to develop interfacial heating solar/photothermal MD systems, ${ }^{23-24}$ in which a hydrophobic microporous membrane with air in its pores separates feed water from permeate flow. The feed side of the membrane was coated with photothermal materials (e.g., silver $\mathrm{NPs}^{23}$ or carbon black NPs-incorporated polyvinyl alcohol ${ }^{24}$ ) and thus can absorb solar radiation and conduct interfacial heating to feed water. The water vapor generated on the feed side immediately goes through the porous membrane and joins the distillate flow on the permeate side. One advantage of interfacial heating MD is that the hydrophobic membrane can confine feed water or distilled water to a designed shape ${ }^{25}$ and control the area of water-air interface for more flexible system design.

The $\eta_{\text {sys }}$ of the interfacial heating MD system was reported as $53.8 \%$ under $700 \mathrm{~W} / \mathrm{m}^{2}$ in one of the pioneering studies ${ }^{24}$ and $68 \%$ under one sun in a more recent study ${ }^{26}$ in which polydopamine particles/bacterial nanocellulose layer served as the solar absorber on the feed side of membrane. 
Neither study considered the electrical energy consumed by the two peristaltic pumps for circulating feed and distilled water when calculating $\eta_{\text {sys }}$, resulting in overestimation of $\eta_{\text {sys. Their }}$ $\eta_{\text {sys }}$ could be further improved if the attenuation of sunlight can be reduced when passing through the feed water before reaching the black feed side of the membrane, or if the pump for circulating the feed water is removed and let the heat accumulate in the feed water chamber. Enhancement of condensation process could also increase its $\eta_{\text {sys. }}$

To achieve an $\eta_{\text {sys }}$ beyond $100 \%$ (i.e., thermodynamic limit), single-stage solar distillation systems can be developed into multistage systems with recovery of condensation heat from the prior stage. A ten-stage MD system had a distillate flux of $3 \mathrm{~L} /\left(\mathrm{m}^{2} \cdot \mathrm{h}\right)$ under $\sim 900 \mathrm{~W} / \mathrm{m}^{2}$ for which

the thermodynamic limit of single-stage solar still is $1.32 \mathrm{~L} /\left(\mathrm{m}^{2} \cdot \mathrm{h}\right) .{ }^{27}$ However, its single-stage $\eta_{\text {sys }}$ was less than $50 \%$ under $\sim 900 \mathrm{~W} / \mathrm{m}^{2}$. Another ten-stage paper towel-wicking system achieved an apparent $\eta_{\text {evp }}$ of $385 \%$ under one sun and an apparent $\eta_{\text {sys }}$ of $\sim 180 \%$ or $2.6 \mathrm{~L} /(\mathrm{kWh})$ under natural sunlight. ${ }^{28}$ Its single-stage system had an $\eta_{\text {evp }}$ of $81 \%$ under one sun. However, the single-stage $\eta_{\text {sys }}$ calculated by measuring the mass of produced distilled water was not reported. Since both systems used capillaries to wick up feed water, it is very likely that the capillaries are subject to clogging when used for drawing turbid raw water, which can result in the decrease of $\eta_{\text {sys. }}{ }^{29}$ So far, no interfacial heating solar distillation system has demonstrated the ability to extract potable water directly from turbid surface water or wastewater, an important water resource for people living in water-stressed areas or periods, not to mention the long-term performance of those systems.

\section{CONCEPT OF PERMEATE-SIDE-HEATED MD}

In this research, a passive, single-stage, permeate-side-heated, interfacial heating solar MD system is developed. This system is mainly comprised of a feed water chamber, a transparent distillation chamber, and a condensing chamber (Figure 1a). Between the feed water and distillation chambers is a hydrophobic $0.45 \mu \mathrm{m}$ polyvinylidene fluoride (PVDF) membrane with the permeate side coated with carbon black NPs contained in black ink. Another type of hydrophobic microporous membrane with the permeate side coated with other photothermal materials may also work. During operation, the feed water filled the feed water chamber by gravity from an elevated reservoir and might partially enter the pores of the membrane (Figure 1b) due to the hydrostatic pressure from the reservoir. The hydrophobicity of the PVDF membrane prevents the feed water from penetrating through the pores due to the capillary effect. The solar radiation without attenuation in liquid is 
absorbed by the black permeate side of the membrane (Figure 1a). The heated permeate side passes thermal energy through conduction to the feed water within the membrane capillaries (Figure 1b), where the evaporation takes place. The steam passes through the membrane and the distillation chamber, and is condensed into distilled water in the condensing chamber (Figure 1a). The driving force for the vapor flow from the membrane to the condensation chamber is the difference between the vapor pressure at the heated water-air interface within the membrane and the lower partial pressure of water vapor in the cooler condensing chamber. The device was placed with an inclination so that droplets of distillate formed on surfaces can slide to the end of the condensing chamber by gravity.

(a)

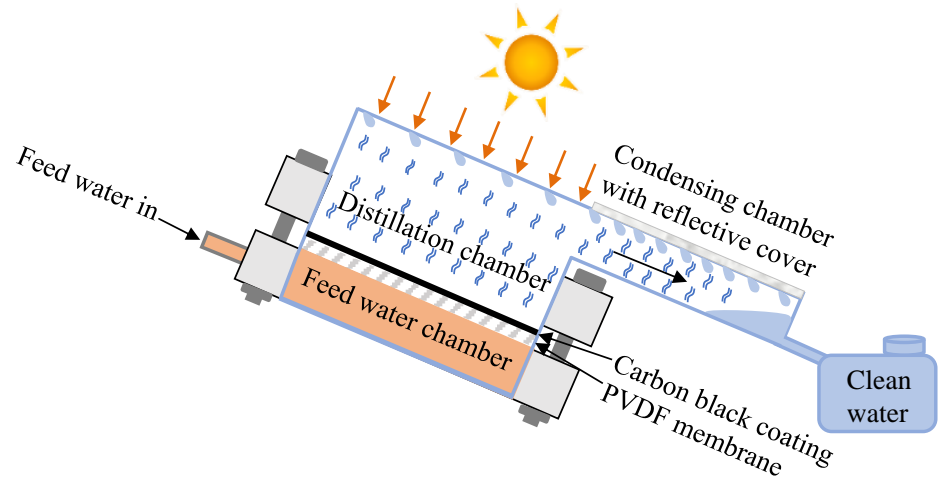

(b)

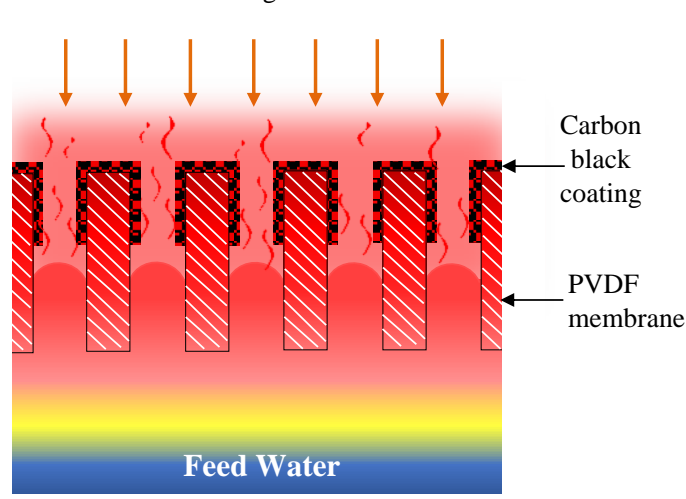

Figure 1. Schematics of (a) the passive, single-stage, permeate-side-heated, interfacial heating solar membrane distillation system, and (b) the interfacial heating of feed water within the capillaries of a PVDF membrane by the black permeate side of membrane through conduction. The schematics are not drawn to scale.

The effective interfacial heating by the permeate side of membrane, the avoidance of incident light attenuation in liquid, the static feed water, and sufficiently long condensation chamber may result in a higher single-stage $\eta_{\text {sys }}$ than the previous interfacial heating MD systems. Placing the membrane on top of feed water avoids the membrane clogging by the sedimentation of large particulates in turbid raw water. There should be no clogging issue in the feed water chamber and inlet tube, either. In real-world applications, there will be an exit for removing the sediments accumulated at the lower end of the feed water chamber. The advantage of this concept over the floating interfacial heating technologies lies in the capability of the hydrophobic membrane of 
confining the feed water within an inclined chamber so that the water-air interface can receive a higher solar irradiation than a horizontal plane. ${ }^{30}$

In this study, the production flux and quality of distilled water extracted from seawater, canal water, and municipal wastewater are examined in both short- and long-term experiments. Although this single-stage system is designed without any heat recovery feature, a multistage system with condensation heat recovery based on the same concept can be achieved and will be studied in future for a higher $\eta_{\text {sys. }}$

\section{RESULTS AND DISCUSSION}

\section{Enhancement of Water Evaporation by the PVDF Membrane with Permeate Side Coated}

with Carbon Black NPs. The effectiveness of permeate side-blackened membrane in enhancing the evaporation of water was verified first by comparing the evaporation rates of deionized (DI) water under $2000 \mathrm{~W} / \mathrm{m}^{2}$ simulated sunlight during 4-hour long experiments when the water surface was covered with an unmodified $0.45 \mu \mathrm{m}$ PVDF membrane, no membrane (just water), and the same PVDF membrane coated with carbon black NPs (Figures. 2a-c). The light fell on the surface of the membrane through a square window $(3 \times 3 \mathrm{~cm})$ rather than the entire beaker opening. The evaporation flux of water covered by the carbon black-coated membrane was $57 \%$ higher than that of bare water and $127 \%$ higher than that of water covered by an unmodified PVDF membrane (Figure 2f). The surface density of carbon black coating was $6.80 \mathrm{~g} / \mathrm{m}^{2}$. The carbon black NPs had a mean hydrodynamic diameter of $133 \mathrm{~nm}$. Here, only the relative comparison of evaporation flux is reported and $\eta_{\text {evp }}$ is not calculated because the water in the beaker received radiation from not only the top opening but also the side of beaker.

The comparison between the scanning electron microscopy (SEM) images of an unmodified membrane (Figure 2d) and a carbon black NPs-coated membrane (Figure 2e) show slight blocking of membrane pores by carbon black NPs, which, however, did not prevent the enhancement of water evaporation. The SEM images at higher magnifications in Figures S1e, and f, Supporting Information (SI), clearly shows the dense deposition of spherical NPs on the membrane after coating (Figure S1f). However, the cross-sectional SEM images (Figures S1g and h) show that there was no noticeable layer of carbon black NPs on the permeate side of the membrane. The thickness of the membrane was measured to be $75-80 \mu \mathrm{m}$ and there are numerous capillary structures within the membrane. 

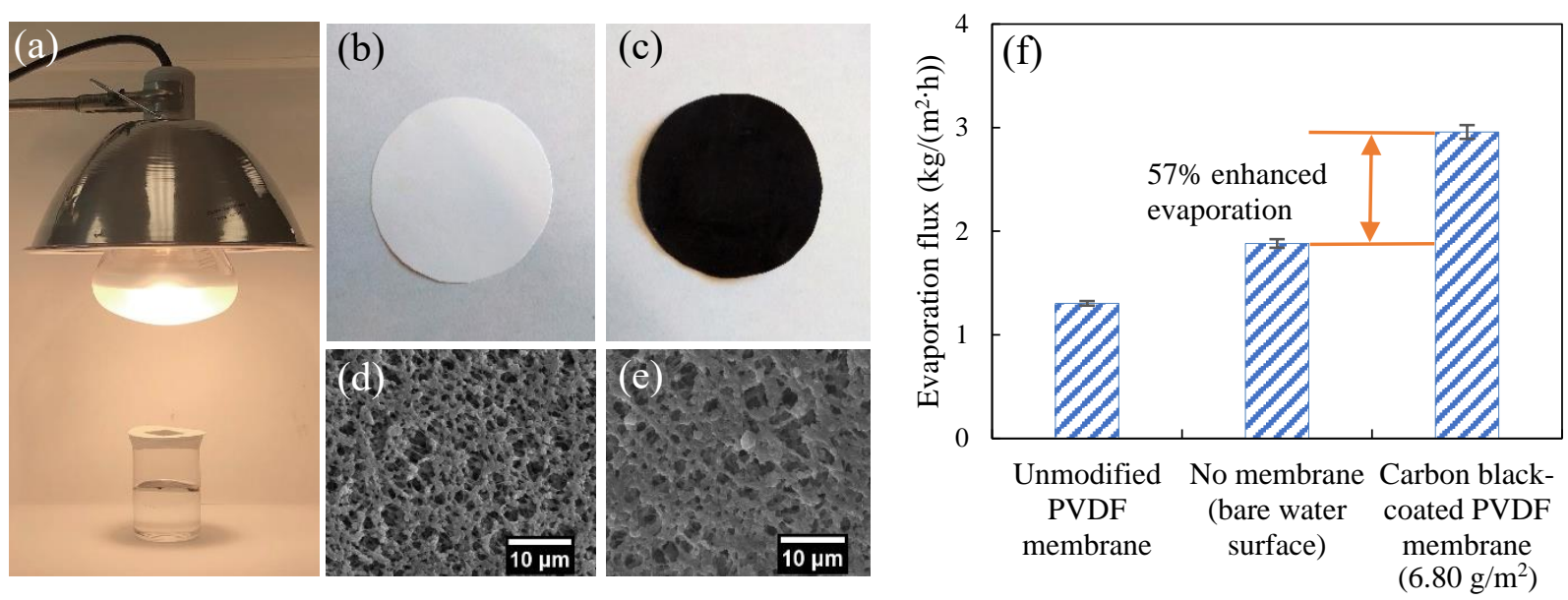

Figure 2. Enhancement of water evaporation by $0.45 \mu \mathrm{m}$ PVDF membrane with permeate side coated with carbon black NPs. (a) A photograph of an evaporation experiment; Photographic images of (b) an unmodified and (c) a carbon black-coated PVDF membrane; SEM images of the (d) unmodified and (e) carbon black-coated PVDF membrane; (f) Water evaporation rates per unit surface area when DI water was covered with an unmodified PVDF membrane, no membrane (just water), and a carbon black-coated PVDF membrane under the simulated sunlight at an irradiance of $2000 \mathrm{~W} / \mathrm{m}^{2}$. The surface density of carbon black coating was $6.80 \mathrm{~g} / \mathrm{m}^{2}$ in $\mathrm{c}$ and $\mathrm{f}$, and $3.31 \mathrm{~g} / \mathrm{m}^{2}$ in e. The error bar represents the standard deviation of duplicate experiments.

More evaporation experiments were performed using PVDF membranes with different surface densities of carbon black NPs ranging from $2.73-10.6 \mathrm{~g} / \mathrm{m}^{2}$. The results showed that the evaporation flux increased from 2.17 to $2.82 \mathrm{~kg} /\left(\mathrm{m}^{2} \cdot \mathrm{h}\right)$ when the surface density of carbon black increased from 2.73 to $3.69 \mathrm{~g} / \mathrm{m}^{2}$ (Figure S2). Further increase in surface density of carbon black from 3.69 to $10.6 \mathrm{~g} / \mathrm{m}^{2}$ did not result in much difference in the evaporation flux, which was within the range of $2.65-3.02 \mathrm{~kg} /\left(\mathrm{m}^{2} \cdot \mathrm{h}\right.$ ) (Figure S2). Thus, the surface density of carbon black coating was maintained within the range of $3.69-10.6 \mathrm{~g} / \mathrm{m}^{2}$ unless mentioned otherwise for all the experiments performed with the permeate-side-heated MD system.

\section{High Energy Efficiency of the Permeate-Side-Heated Interfacial Heating MD System in} Producing Distilled Water under Natural Sunlight. The distillate production rates of the permeate-side-heated MD system were measured under natural sunlight (Figure 3a) and different weather conditions. The device was placed facing south with an inclination of $30^{\circ}$ and the feed 
water was DI water. The inclination of system needs to be optimized in future studies as it affects the incident solar irradiation ${ }^{30}$ and the gravity-driven flow of water drops condensed on the walls. Although the experiments were conducted for 24 hours during the day, all the distilled water collected was produced during the daytime. The amount of distilled water condensed during nighttime was negligible and uncollectible.

The distillate production rates per unit area of membrane (or distillate flux) were 2.18 $\mathrm{kg} /\left(\mathrm{m}^{2}\right.$.day) during a rainy day in August (time-weighted average irradiance of daytime, i.e., sunrise to sunset, $\left.=340 \mathrm{~W} / \mathrm{m}^{2}\right), 3.64 \mathrm{~kg} /\left(\mathrm{m}^{2} \cdot\right.$ day) during a cloudy day in September (daytime irradiance $\left.=492 \mathrm{~W} / \mathrm{m}^{2}\right), 2.63 \mathrm{~kg} /\left(\mathrm{m}^{2} \cdot\right.$ day $)$ during a sunny day in January (daytime irradiance $=$ $\left.320 \mathrm{~W} / \mathrm{m}^{2}\right)$, and $8.56 \mathrm{~kg} /\left(\mathbf{m}^{2} \cdot\right.$ day) during a sunny day in July (daytime irradiance $=\mathbf{6 5 2} \mathbf{W} / \mathbf{m}^{2}$, $3.31 \mathrm{~g} / \mathrm{m}^{2}$ carbon black coating), as shown in Figure $3 \mathrm{~b}$. The irradiance variation of the natural sunlight during the daytime on those four days are shown in Figure S3. The solar energy efficiency of the system in producing distilled water $\left(\eta_{\text {sys }}\right)$ is calculated as below ${ }^{21}$ :

$$
\eta_{s y s}=\frac{\Delta H_{v a p} \times M_{W}}{E_{e} \times t}
$$

where $\Delta H_{\text {vap }}$ is the enthalpy of water vaporization, $2435 \mathrm{~kJ} / \mathrm{kg}$, at $27{ }^{\circ} \mathrm{C}^{31}, M_{\mathrm{w}}$ is the mass of distilled water produced per unit area of membrane during the day, $\mathrm{kg} / \mathrm{m}^{2}$, which was calculated by dividing the mass of distilled water collected from the condensation chamber at the end of the daytime by the area of black membrane $(5 \mathrm{~cm} \times 5 \mathrm{~cm})$ exposed to the sunlight; $E_{\mathrm{e}}$ is the timeweighted average ambient solar irradiance during the daytime (sunrise to sunset) where the system was placed, $\mathrm{kW} / \mathrm{m}^{2} ; t$ is the time length of daytime, in second. The $\boldsymbol{\eta}_{\text {sys }}$ is $67.5 \%$ during the sunny day in July (Figures 3b and S3d, $t=13.15 \mathrm{~h}$ ), and is the highest so far for single-stage solar distillation systems under natural sunlight to the best of our knowledge. The $\eta_{\text {sys }}$ are $33.4 \%, 43.7 \%$, and $52.5 \%$ during the rainy, cloudy, and the sunny day in January, respectively, (Figures $3 \mathrm{~b}$ and $\mathrm{S} 3, t=13.00 \mathrm{~h}, 11.45 \mathrm{~h}$, and $10.58 \mathrm{~h}$, respectively). The $\eta_{\text {sys }}$ of the rainy and cloudy days are lower than sunny days even though their irradiances were higher than the sunny day in January, likely due to frequent and long disruption of direct solar radiation and heat accumulation on the black permeate side of the membrane. The $\eta_{\text {sys }}$ on a sunny day is higher in July than in January because the higher irradiance leads to a higher temperature and vapor pressure at the water-air interface.

Duplicate 24-hour long experiments were performed for different weather conditions. The distillate flux was $4.51 \mathrm{~kg} /\left(\mathrm{m}^{2} \cdot\right.$ day) during the other rainy day (time-weighted average irradiance 
of 9:15 $\mathrm{AM}-6: 00 \mathrm{PM}=433 \mathrm{~W} / \mathrm{m}^{2}$ in May $), 6.08 \mathrm{~kg} /\left(\mathrm{m}^{2} \cdot\right.$ day $)$ during the other cloudy day (irradiance of 6:38 AM-6:00 PM $=584 \mathrm{~W} / \mathrm{m}^{2}$ in June), and $8.24 \mathrm{~kg} /\left(\mathrm{m}^{2}\right.$.day) during another sunny day (irradiance of 7:00 AM-6:30 PM = 697 W/m² in September) (Figure S4).
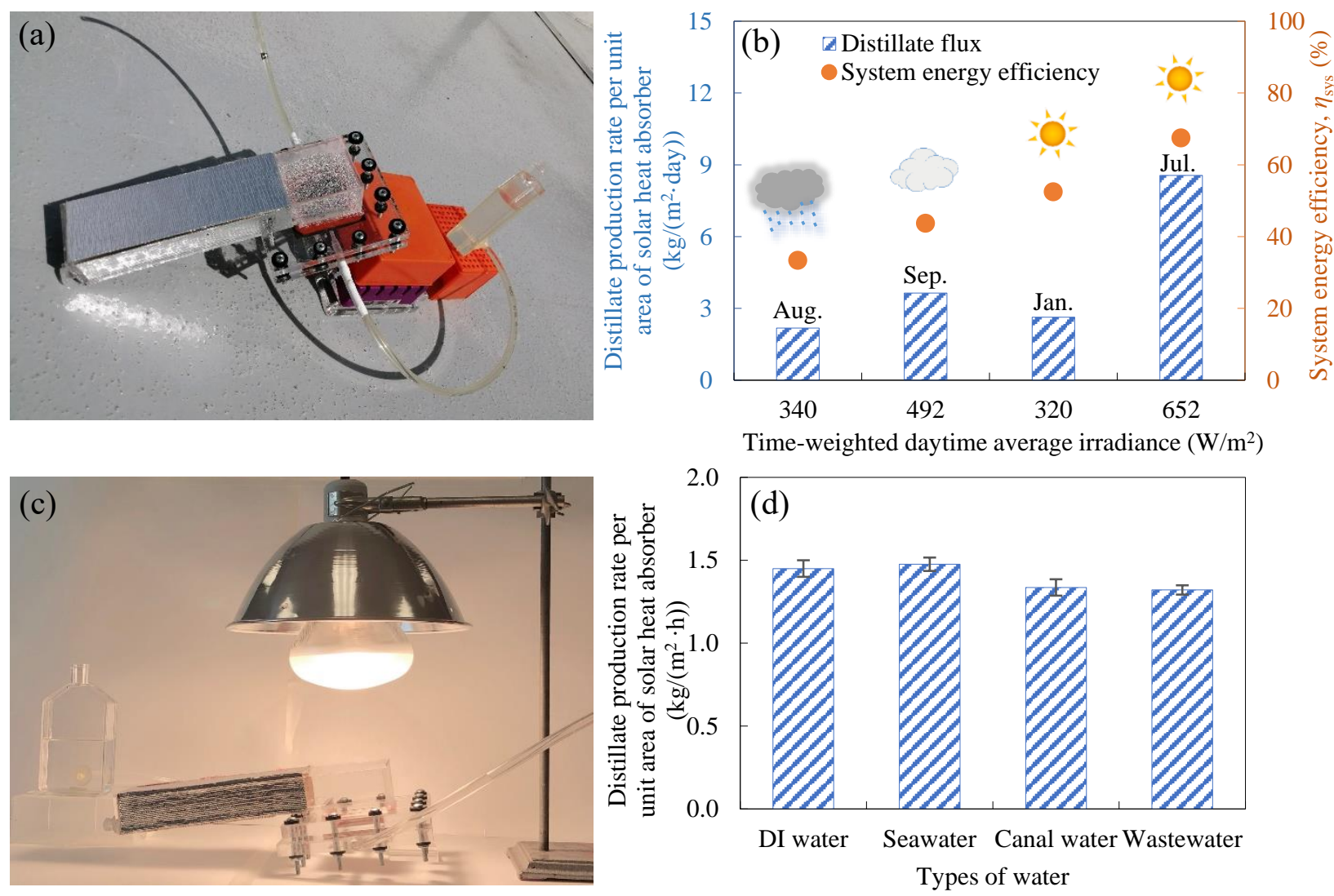

Figure 3. Photographs of the permeate-side-heated MD system under (a) natural sunlight and (c) simulated sunlight. (b) Distillate production rates per unit area of solar heat absorber (i.e., the black membrane) and corresponding system energy efficiencies at different daytime (sunrise to sunset) average irradiances and weather conditions under natural sunlight. (d) Distillate flux during 4-hour long experiments under the simulated sunlight at an irradiance of $1800 \mathrm{~W} / \mathrm{m}^{2}$ using different types of feed water. Error bars represent the standard deviation of duplicate experiments.

High Initial Production Flux and Quality of Distilled Water Extracted from Seawater, Canal Water, and Municipal Wastewater under Simulated Sunlight. Figure 3c shows the photograph of a permeate-side-heated MD system working under the simulated sunlight with the irradiance $=$ 
$1800 \mathrm{~W} / \mathrm{m}^{2}$ at the level of the center of the membrane. The system had an inclination of $10^{\circ}$. The average distillate flux was $1.45 \mathrm{~kg} /\left(\mathrm{m}^{2} \cdot \mathrm{h}\right)$ when DI water was used as feed water (Figure $3 \mathrm{~d}$ ), resulting in $\eta_{\text {sys }}=54 \%$. The $\eta_{\text {sys }}$ under simulated sunlight is lower than that on the sunny day in July (Figure 3b) likely because the condensation process became the bottleneck of mass transport under the high irradiance of simulated sunlight. The average distillate flux extracted from seawater, canal water, and municipal wastewater during the initial 4-hour operation under the same simulated sunlight was $1.48,1.34$, and $1.32 \mathrm{~kg} /\left(\mathrm{m}^{2} \cdot \mathrm{h}\right)$, respectively. The initial distillate flux from all four types of feed water varied within $5.7 \%$ difference from their average, $1.40 \mathrm{~kg} /\left(\mathrm{m}^{2} \cdot \mathrm{h}\right)$, as shown in Figure 3d, showing the independence of initial distillate flux from the type of feed water. Although the vapor pressure of seawater (total dissolved solid ${ }^{32}$ estimated as $37.3 \mathrm{~g} / \mathrm{L}$ in this study) is $2 \%$ lower than that of pure water, ${ }^{33}$ the distillate flux from seawater was slightly higher than that from DI water likely due to the smaller contact angle of saline water on PVDF membrane compared to DI water, ${ }^{34}$ which partially resulted from the increased surface tension between air and the water at a higher salinity. ${ }^{33-34}$ The greater ability to wet PVDF might make seawater closer to the heated permeate side of membrane and more effectively evaporated than DI water. The distillate fluxes of canal water and wastewater were slightly lower than DI water possibly due to their higher turbidities (Figure 4d) and the pore-blocking effect of particulates.

Despite the clear appearance of distilled water compared to raw feed water (Figures 4a-c), the quality of distilled water extracted from all three types of feed water during the first 8-hour operation was quantified by measuring their heterotrophic plate count (HPC), turbidity, electrical conductivity, and chemical oxygen demand (COD), which are commonly used to indicate the concentrations of bacteria, suspended particulates, total dissolved solids, and organic matter in water, respectively. Two different batches of each type of feed water were collected on different days for such quantification. The average colony-forming units (CFU) of heterotrophic bacteria in triplicate HPC tests of seawater, canal water, and wastewater were $1.6 \times 10^{2}\left(\mathrm{std} . \mathrm{dev} .=1.1 \times 10^{2}\right)$, $5.8 \times 10^{4}\left(\right.$ std. dev. $\left.=5.2 \times 10^{3}\right)$, and $1.7 \times 10^{6}\left(\right.$ std. dev. $\left.=5.2 \times 10^{5}\right) \mathrm{CFU} / \mathrm{mL}$, respectively. The petri dish photographs of one of the triplicate HPC tests are shown in Figures 4a-c. In striking contrast, the distilled water extracted from all types of feed water had $0 \mathrm{CFU} / \mathrm{mL}$, well below the standard of HPC ( $<500 \mathrm{CFU} / \mathrm{mL})$ set by the National Primary Drinking Water Regulations (NPDWR) of United States. In addition, no protozoan was found in distilled water samples under an optical microscope. Thus, the produced distilled water was likely free of microorganism. 

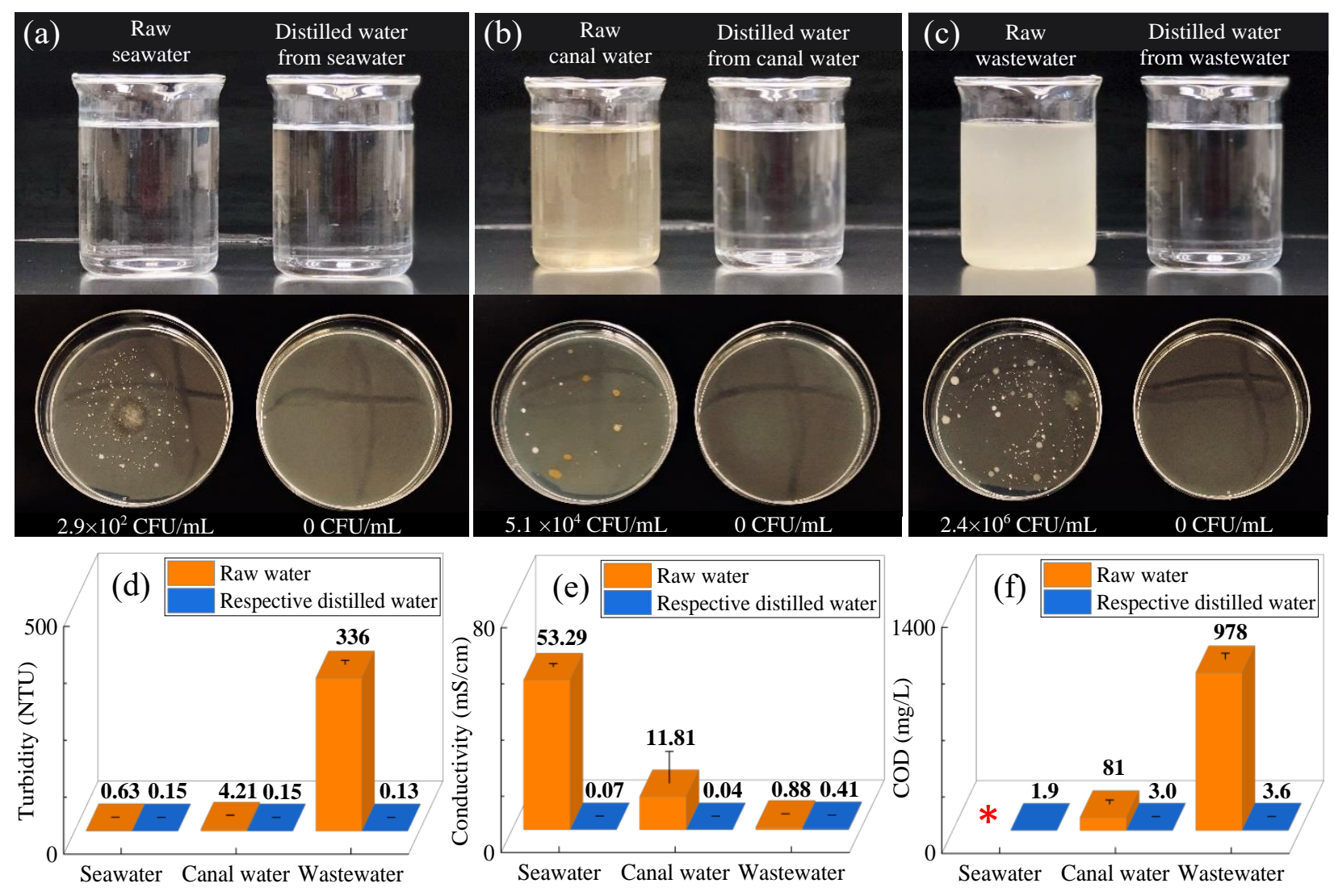

Figure 4. The visual comparison and results of one of the triplicate heterotrophic plate count (HPC) tests of (a) raw seawater, (b) raw canal water, (c) raw municipal wastewater, and their respective distilled water. Canal water and wastewater were diluted 100 and 1000 times, respectively, for HPC tests. Significant reduction of (d) turbidity, (e) electrical conductivity, and (f) chemical oxygen demand (COD) of distilled water compared to raw feed water during the first 8 hours of operation under the simulated sunlight $\left(1800 \mathrm{~W} / \mathrm{m}^{2}\right)$. ${ }^{*} \mathrm{COD}$ of seawater could not be measured due to the severe interference by $\mathrm{Cl}^{-}$. The error bars represent standard deviations of results obtained from two different batches of raw water that were collected on different days.

When extracted from raw seawater (0.63 NTU), canal water (4.21 NTU), and municipal wastewater (336 NTU), the turbidity of respective distilled water dropped to $0.15,0.15$, and 0.13 NTU on average (Figure 4d), all below the standard of 0.3 NTU set in NPDWR. The electrical conductivity of distilled water was also significantly reduced from seawater $(52.39 \mathrm{mS} / \mathrm{cm})$, canal water $(11.81 \mathrm{mS} / \mathrm{cm})$, and wastewater $(0.88 \mathrm{mS} / \mathrm{cm})$ to $0.07,0.04$, and $0.41 \mathrm{mS} / \mathrm{cm}$ on average, respectively (Figure 4e). The higher conductivity of distilled water extracted from wastewater is 
likely due to the ammonia escaped from wastewater to distilled water. The average COD of the raw canal water and wastewater was 81 and $978 \mathrm{mg} / \mathrm{L}$, respectively, whereas the COD of seawater could not be measured due to severe interference by $\mathrm{Cl}^{-}$anions. The distilled water produced from seawater, canal water, and wastewater had the COD of 1.9, 3.0, and 3.6 mg/L, respectively (Figure 4f). The $99.9 \%$ removal of turbidity and $99.6 \%$ removal of COD from wastewater, as well as $99.9 \%$ reduction of electrical conductivity from seawater demonstrate the effectiveness of the system in removing particulates (including microorganisms), and organic matter, as well as in desalination.

\section{Long-Term Production of Potable Distilled Water from Seawater, Canal Water, and} Municipal Wastewater under Simulated Sunlight. The long-term performance of the system was evaluated by determining the life span of the membrane and quantifying the decrease in flux and quality of distilled water when the system operated daily until the feed water completely wet and penetrated the hydrophobic PVDF membrane. On each day, the experiment was 8-hour long under the simulated sunlight $\left(1800 \mathrm{~W} / \mathrm{m}^{2}\right)$. As shown in Figure 5a, the system operated for 32, 18, and 10 consecutive days on average before the penetration of membrane occurred when two different batches of seawater, canal water, and municipal wastewater were used as the feed water, respectively. Replacement or regeneration of membrane is needed for continuous operation and will be studied in future.

Membrane wetting in MD systems is primarily due to severe inorganic scaling or organic fouling on the membrane. ${ }^{35-36}$ Since seawater has high concentrations of inorganic electrolytes, scaling may have occurred inside the pores of membrane where the evaporation of water took place. The accumulated inorganic precipitates inside the pores can reduce capillary pressure by reducing the hydrophobicity of the membrane, leading to wetting of the pores and, eventually, the penetration of membrane. ${ }^{35}$ In the case of canal water, a brown fouling layer formed on the feed side of the membrane at the end of a 22-day experiment (Figure S5c), which is probably due to the adsorption of natural organic matter, the presence of which is implied by the brownish color (Figure 4b) and $81 \mathrm{mg} / \mathrm{L} \mathrm{COD} \mathrm{(Figure} \mathrm{4f)} \mathrm{of} \mathrm{canal} \mathrm{water.} \mathrm{Thus,} \mathrm{it} \mathrm{is} \mathrm{likely} \mathrm{that} \mathrm{the} \mathrm{organic} \mathrm{fouling}$ reduced the hydrophobicity of the membrane and resulted in membrane penetration in canal water experiments. Interestingly, the fouling on the feed side of the membrane observed at the end of an 11-day experiment with wastewater (Figure S5d) does not appear as severe as that with canal water 
(Figure S5c). It is reported that municipal wastewater has high concentrations of surfactants (10$20 \mathrm{mg} / \mathrm{L})^{37-38}$, which can significantly reduce the hydrophobicity of membrane and consequently lead to membrane wetting. ${ }^{35,39}$ Thus, we speculate that surfactants in the wastewater may be the main reason for the shortest life span of membrane (Figure 5a) even though they did not leave much stains on the feed side of the membrane (Figure S5d).
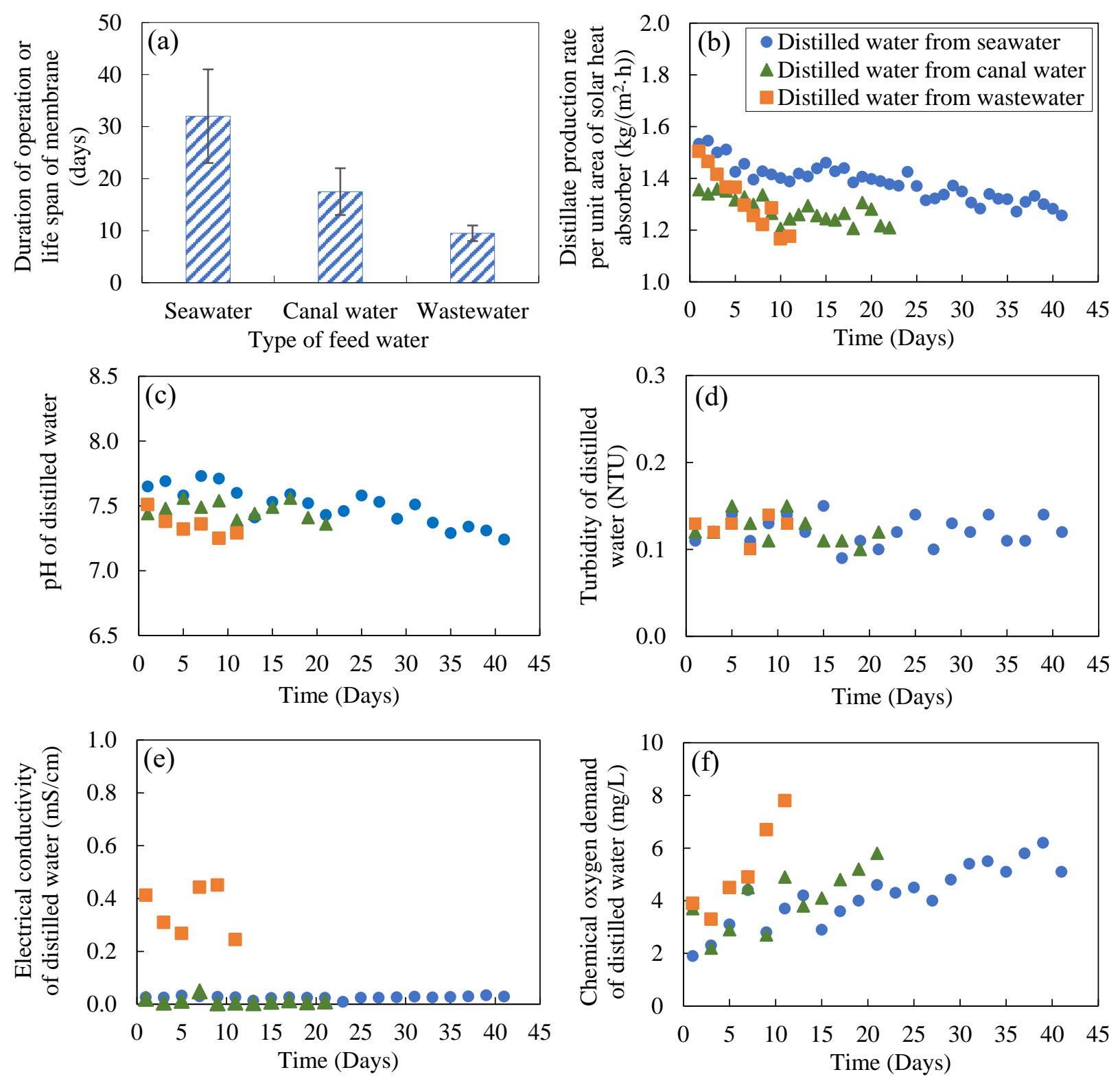

Figure 5. Long-term production of potable distilled water from seawater, canal water, and municipal wastewater. (a) Average duration of long-term experiments before the feed water penetrated the membrane. Error bars represent standard deviations of duplicate experiments using different batches of feed water that were collected on different days. (b) Distillate production 
rate per unit area of solar heat absorber (i.e., black membrane), (c) pH, (d) turbidity, (e) electrical conductivity, and (f) chemical oxygen demand of the distilled water extracted from seawater (circles), canal water (triangles), and wastewater (squares) on different days during one of the duplicate long-term experiments. On each day, the system operated for 8 hours under the simulated sunlight at an irradiance of $1800 \mathrm{~W} / \mathrm{m}^{2}$.

Figures 5b-f present the variation of production flux, $\mathrm{pH}$, turbidity, electrical conductivity, and COD, respectively, of distilled water extracted from different types of feed water during one of the duplicate long-term experiments. The distillate flux dropped $18.2 \%$ from 1.54 to 1.26 $\mathrm{kg} /\left(\mathrm{m}^{2} \cdot \mathrm{h}\right)$ over 41 days with seawater, $11.0 \%$ from 1.36 to $1.21 \mathrm{~kg} /\left(\mathrm{m}^{2} \cdot \mathrm{h}\right)$ over 22 days with canal water, and $22.0 \%$ from 1.50 to $1.17 \mathrm{~kg} /\left(\mathrm{m}^{2} \cdot \mathrm{h}\right)$ over 11 days with wastewater (Figure $5 \mathrm{~b}$ ), likely due to the scaling and fouling on the feed side and in the pores of membranes as discussed above. There was no obvious trend of change in $\mathrm{pH}$ (7.24-7.73), turbidity (0.09-0.15 NTU), or electrical conductivity $(0.003-0.049 \mathrm{mS} / \mathrm{cm}$ for seawater and canal water; $0.245-0.451 \mathrm{mS} / \mathrm{cm}$ for wastewater) throughout long-term experiments. The COD of distilled water had increasing trends during long-term experiments: $1.9-6.2 \mathrm{mg} / \mathrm{L}$ with seawater, $2.2-5.8 \mathrm{mg} / \mathrm{L}$ with canal water, and 3.3-7.8 $\mathrm{mg} / \mathrm{L}$ with wastewater. The distillate flux and quality of distilled water had similar trend and range of values in the other duplicate long-term experiments (Figure S6).

Comprehensive water quality tests were performed by National Testing Laboratories, Ltd. (Cleveland, Ohio, United States) for the distilled water accumulated for each type of feed water throughout the entire period of long-term experiments shown in Figures 5b-f. The distilled water was stored in glass containers in the dark at $3{ }^{\circ} \mathrm{C}$ before sending for tests in the company's sampling kit with an ice pack. The results (Table. S1) show that the distilled water extracted from all types of feed water meets United States National Primary and Secondary Drinking Water Regulations for total coliform and E. coli, 22 heavy metals and minerals, seven anions, five physical factors, four trihalomethanes, and 47 volatile organic compounds except for dichloromethane (0.007$0.810 \mathrm{mg} / \mathrm{L}$ found in distilled water). In addition, the concentration of methyl ethyl ketone was found to be $0.70-3.10 \mathrm{mg} / \mathrm{L}$ even though it is not regulated. It is almost certain that the dichloromethane and methyl ethyl ketone came from the acrylic cement (SCIGRIP $\left.{ }^{\circledR} 16\right)$ used for bonding the acrylic pieces that constitute the system because $30-60 \%$ of the glue is dichloromethane and $10-30 \%$ is methyl ethyl ketone by weight. Avoiding using this product in real-world applications is expected to make the distilled water free of these two compounds. Thus, 
we can conclude that the distilled water produced by the system will be safe to drink in real-world applications.

\section{CONCLUSION}

This passive, single-stage, permeate-side-heated, interfacial heating solar MD system can produce potable water from seawater, canal water, and municipal wastewater at a system solar efficiency of $\sim 67 \%$ on a sunny summer day in South Florida. Taking two liters as the average daily intake requirement of drinking water for an adult to survive, ${ }^{40}$ this system with $1 \mathrm{~m}^{2}$ carbon black NPscoated membrane is expected to produce enough potable water $(8.56 \mathrm{~L})$ for four persons at an average daytime irradiance of $652 \mathrm{~W} / \mathrm{m}^{2}$ or higher. The high system energy efficiency is probably attributed to the effective interfacial heating of feed water through conduction by the ultrathin permeate-side-heated membrane, little attenuation of the incident sunlight, and sufficient surface for condensation. The system can operate for 32, 18, and 10 days on average under simulated sunlight $\left(1800 \mathrm{~W} / \mathrm{m}^{2}\right)$ with seawater, canal water, and municipal wastewater as the feed water, respectively, before the feed water penetrates the $0.45 \mu \mathrm{m}$ PVDF membrane. Continuous operation would require replacement or regeneration of the membrane. The comprehensive water quality tests show that the distilled water accumulated for each type of feed water throughout long-term experiments meets United States National Primary and Secondary Drinking Water Regulations for E. coli, total coliform, 22 heavy metals, seven anions, five physical factors, four trihalomethanes, and 46 VOCs, and thus will be safe to drink in real-world applications. This passive system has the potential to be an energy-efficient, low-cost, and off-grid domestic drinking water production system, if successfully scaled up. Optimization of the system design in future is needed to further increase its $\eta_{\text {sys, }}$, such as optimization of geometries and material of distillation and condensation chambers, inclination of the system, membrane antifouling and antiwetting strategies, materials and pore size of the membrane, and condensation enhancement technologies.

\section{EXPERIMENTAL SECTION}

Materials and Equipment. The main structure of the system was built using transparent polymethyl methacrylate (PMMA) sheets with two different thicknesses, 1/8 and 1/2 inch. The $0.45 \mu \mathrm{m}$ hydrophobic PVDF flat sheet membrane was purchased from Fisher Scientific (catalog No. 88518). It was reported that this membrane has a contact angle of $124^{\circ}$, a porosity of $74 \%$, 
and a liquid entry pressure of $180 \mathrm{kPa}^{41}{ }^{4}$ Speedball ${ }^{\circledR}$ super black ink was used as the source of carbon black nanoparticles (NPs). The ink contains 2-dimethylaminoethanol and aqueous borated shellac along with carbon black NPs. The sealing gaskets were made of silicone rubber (Grainger, Item No. 1MWF2). A reflective heat barrier (Thermo-Tec, Part No. 13575) was used to prevent the exposure of the condensing chamber to the light. Osram Ultra-Vitalux $300 \mathrm{~W}$ bulbs were used for producing the simulated sunlight. ${ }^{42}$

The DI water (Millipore, MA) had a resistivity of $18.2 \mathrm{M} \Omega \cdot \mathrm{cm}$. The seawater was collected from the Atlantic Ocean, at a beach in Boca Raton, Florida, USA (26 21' 2.3724" N and 80 4' 8.4288" W). The raw canal water was collected from the Spanish River Gulf Stream, Florida, USA $\left(26^{\circ} 21^{\prime} 27.5652^{\prime \prime} \mathrm{N}\right.$ and $\left.80^{\circ} 5^{\prime} 53.9736^{\prime \prime} \mathrm{W}\right)$. The canal water and seawater samples were collected 3-5 $\mathrm{ft}$ away from the shore and $1 \mathrm{ft}$ down from the water surface. The raw municipal wastewater was collected from the Boca Raton Wastewater Plant, Florida, USA. The sampled seawater and canal water were stored in sealed glass containers, and the wastewater was stored in sealed plastic containers in the dark at $3{ }^{\circ} \mathrm{C}$. The raw water started being used for long-term experiments on the same day they were collected, and were stored at $3{ }^{\circ} \mathrm{C}$ in dark throughout the long-term experiments. The quality of the seawater, canal water, and municipal wastewater used in the longterm experiments is presented in Table S2. The temperature of feed water was not particularly controlled in all experiments. Under simulated sunlight, the temperature of feed water increased from the initial $22^{\circ} \mathrm{C}$ to $32^{\circ} \mathrm{C}$ after 8 hours of illumination, the average of which was $27^{\circ} \mathrm{C}$. Under the natural sunlight, the feedwater temperature in the reservoir ranged from $22{ }^{\circ} \mathrm{C}$ to $38{ }^{\circ} \mathrm{C}$ with an average of $30^{\circ} \mathrm{C}$ during the daytime of the cloudy day shown in Figure $3 \mathrm{~b}$.

SEM Imaging of Membranes. A JSM 6335F series SEM was used for characterizing PVDF membranes before and after coating with carbon black NPs, in secondary electron imaging mode in which the electrons are emitted from a very close source of emission. Since PVDF is nonconductive, they were coated with gold NPs $(5-10 \mathrm{~nm})$ by a low-vacuum sputter coating method before being attached to the specimen stage and inserted into SEM for imaging in a vacuum condition.

Development of the Permeate-Side-Heated MD System. The system is comprised of a feed water chamber, a distillation chamber, and a condensing chamber, the dimensions of which are 50 $\mathrm{mm}(\mathrm{L}) \times 50 \mathrm{~mm}(\mathrm{~W}) \times 15 \mathrm{~mm}(\mathrm{H}), 67 \mathrm{~mm}(\mathrm{~L}) \times 67 \mathrm{~mm}(\mathrm{~W}) \times 55 \mathrm{~mm}(\mathrm{H})$, and $206 \mathrm{~mm}(\mathrm{~L}) \times$ 
$67 \mathrm{~mm}(\mathrm{~W}) \times 36 \mathrm{~mm}(\mathrm{H})$, respectively. Both chambers were made of transparent 1/8-inch PMMA sheets. The condensing chamber was wrapped with a reflective heat barrier (Thermo-Tec, Part No. 13575). Between the distillation chamber and the feed water chamber is a $0.45 \mu \mathrm{m}$ PVDF membrane, which has an active surface area of $25 \mathrm{~cm}^{2}(5 \mathrm{~cm} \times 5 \mathrm{~cm})$. The permeate side of the membrane was coated with carbon black NPs (Speedball ${ }^{\circledR}$ super black ink) by evenly spreading the ink over the membrane surface and drying it in the air. This ink did not penetrate to the other side (feed side) of the membrane. One custom-made silicone rubber (Grainger, Item No. 1MWF2) gasket was placed between the membrane and the feed water chamber for preventing the leak of feed water. Another silicone rubber gasket was positioned between the membrane and the distillation chamber to avoid the leaking of water vapor. The feed chamber and the distillation chamber were pressed together using vertical machine screws and nuts, which provide adequate pressure on the membrane and gaskets. Six identical systems were used during this entire study. Around 40 different carbon black-coated membranes were used in total for the membrane distillation experiments. The transparent PMMA top window of the distillation chamber was replaced every 2-3 days during the long-term experiments due to the deterioration in transparency under constant exposure of intense simulated sunlight.

Experiments under Natural Sunlight. All the experiments under natural sunlight were performed on the Boca Raton campus of Florida Atlantic University (26 $22^{\circ} 22.296^{\prime \prime} \mathrm{N}$ and 80 $0^{\circ}$ 11.5812" W), except for the sunny day experiment in July shown in Figure 3b, which was

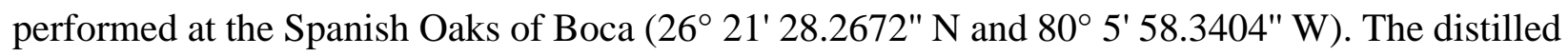
water accumulated in the condensation chamber during the day was collected right after the sunset and measured by an analytical balance (LF-224 R, Intelligent Weighing Technology) for the mass. Other information regarding the experiments shown in Figure $3 b$ is: the rainy day was August 4, $2019, \mathrm{~T}=29^{\circ} \mathrm{C}$; the cloudy day was September $23,2020, \mathrm{~T}=28{ }^{\circ} \mathrm{C}$; the sunny day in January was January $27,2021, \mathrm{~T}=26.4^{\circ} \mathrm{C}$; and the sunny day in July was July $8,2018, \mathrm{~T}=27^{\circ} \mathrm{C}$. For the other duplicate experiments shown in Figure S4, the rainy day was May $31,2018, \mathrm{~T}=27^{\circ} \mathrm{C}$, the cloudy day was June $5,2018, \mathrm{~T}=29^{\circ} \mathrm{C}$, and the sunny day was September $18,2018, \mathrm{~T}=29^{\circ} \mathrm{C}$.

Water Quality Assessment. The turbidity was measured using a Hach 2100Q Turbidity meter in Nephelometric Turbidity Units (NTU). A Fisher Scientific Education benchtop pH meter was used for $\mathrm{pH}$ measurement. A Zetasizer Nano ZS 90 (Malvern) was used to measure the electrical conductivity at $25^{\circ} \mathrm{C}$ in its zeta potential mode. The dichromate reflux method was used to measure 
COD. This method uses a strong oxidizing agent, potassium dichromate $\left(\mathrm{K}_{2} \mathrm{Cr}_{2} \mathrm{O}_{7}\right)$, for sample digestion at $150{ }^{\circ} \mathrm{C}$ for 2 hours. The dichromate consumption $\left(\mathrm{Cr}_{2} \mathrm{O}_{7}{ }^{2-}\right.$ reduced to $\left.\mathrm{Cr}^{3+}\right)$ after $2 \mathrm{~h}$ oxidation reaction is converted to the amount of oxygen required to oxidize the same oxidizable organics (i.e., COD). A UV-Vis Spectrophotometer (Hach DR5000) was used to quantify the dichromate consumptions by measuring the concentration of either the produced $\mathrm{Cr}^{3+}$ at $620 \mathrm{~nm}$ for feed water or the remaining $\mathrm{Cr}_{2} \mathrm{O}_{7}{ }^{2-}$ at $350 \mathrm{~nm}$ for distilled water. A $300 \mathrm{mg} / \mathrm{L}$ standard COD solution was used to validate the COD readings.

HPC tests were performed using the spread plate method. Agar R2A (18.2 g/L) was used as the nutrient of the culture medium. $0.1 \mathrm{~mL}$ of water sample was evenly spread on the Agar R2A media in Petri dishes using an L-spreader and then incubated for 72 hours at $35{ }^{\circ} \mathrm{C}$. ${ }^{43}$ After incubation, the number of bacteria colonies that had formed on the culture media were numerated and reported in CFU/mL. For HPC tests, no dilution was done for raw seawater and all distilled water samples. However, raw canal water and municipal wastewater samples were diluted by 100 and 1000 times, respectively, before putting the $0.1 \mathrm{~mL}$ on the culture medium. The Petri dishes for distilled water presented in Figures 4a-c were prepared using the distilled water extracted from seawater on Day 18, the distilled water extracted from canal water on Day 10, and the distilled water extracted from municipal wastewater on Day 4, respectively, during the duplicate long-term experiments shown in Figure S6. The distilled water in beakers presented in Figures 4a-c was collected during the last four days of the duplicate long-term experiments shown in Figure S6.

\section{Calibration of Signstek Solar Power Irradiance Meter (TES 1333) with LP02-LI19}

Pyranometer. The Signstek Solar Power Irradiance Meter (Model: TES 1333) and LP02-LI19 pyranometer (Hukseflux) were used for measuring the irradiance. When TES 1333 was used, the irradiance of natural sunlight was manually measured every hour. When LP02-LI19 was used, the irradiance of natural sunlight was automatically measured every 30 seconds. TES 1333 has a nominal spectral response for 400-1100 nm wavelength. Thus, the reading of TES 1333 was calibrated using an LP02-LI19 pyranometer (Hukseflux) that has a nominal spectral response for 285-3000 nm wavelength for both natural and simulated sunlight. Interestingly, the readings of the two irradiance meters did not have much difference under natural sunlight, with the linear relationship as LP02-LII9 reading $=1.0063 \times T E S 1333$ reading $+34.18, \mathrm{R}^{2}=0.9948$ with 12 calibration measurements (Figure S7). Thus, all the irradiance readings of TES 1333 were converted to LP02-LI19 readings that are reported in this study. 


\section{ASSOCIATED CONTENT}

\section{Supporting Information}

Scanning electron microscopy images of an unmodified and a carbon black NPs-coated PVDF membrane (Figure S1); evaporation flux of DI water under the simulated sunlight when covered with the PVDF membrane with different surface densities of carbon black NPs (Figure S2); irradiance variation of natural sunlight during the daytime of the rainy, cloudy, and sunny days shown in Figure 3b (Figure S3); the distillate production fluxes of the permeate-side-heated MD system during the duplicate 24-hour experiments and the irradiance variation in different weather conditions (Figure S4); photographs of the feed side of an unmodified PVDF membrane and the PVDF membranes after long-term experiments (Figure S5); the duplicate long-term experimental results of flux, turbidity, electrical conductivity, $\mathrm{COD}$, and $\mathrm{pH}$ of the distillate from all three types of raw water (Figure S6); calibration curve of Signstek Solar Power Irradiance Meter (TES 1333) by LP02-LI19 Pyranometer under natural sunlight (Figure S7); comprehensive quality report of the distilled water accumulated throughout the entire period of long-term experiments shown in Figures 5b-f (Table S1); the quality of two batches of seawater, canal water, and municipal wastewater used as the feed water (Table S2).

\section{COMPETING INTERESTS}

A patent application has been filed for the passive permeate-side-heated solar MD system including the modules that can confine feed water into different shapes.

\section{ACKNOWLEDGMENTS}

The work was financially supported by Florida Atlantic University (FAU). We thank Dr. Daniel Meeroff, Department of Civil, Environmental and Geomatics Engineering, FAU, for letting us use the autoclave, turbidity meter, and UV-Vis Spectrophotometer as well as Dr. Myeongsub Kim, Department of Ocean and Mechanical Engineering, FAU, for letting us use the laser cutter. We thank Mr. Mark Liburdi, Boca Raton Wastewater Plant, for providing raw municipal wastewater. 
We also thank Mr. Jonathan Comparan, Advanced Materials Engineering Research Institute (AMERI), Florida International University, for helping us with SEM imaging of the membrane.

\section{REFERENCES}

1. Mekonnen, M. M.; Hoekstra, A. Y., Four billion people facing severe water scarcity. Sci. Adv. 2016, 2 (2), 1500323.

2. Gude, V. G., Desalination and water reuse to address global water scarcity. Rev. Environ. Sci. Bio/Tech. 2017, 16 (4), 591-609.

3. Montgomery, M. A.; Elimelech, M., Water and sanitation in developing countries: including health in the equation. Environ. Sci. Technol. 2007, 41 (1), 17-24.

4. Corey, C. M.; Deitch, E. A., Factors Affecting Business Recovery Immediately after Hurricane Katrina. Journal of Contingencies and Crisis Management 2011, 19 (3), 169-181.

5. Cortés, J., Puerto Rico: Hurricane Maria and the Promise of Disposability. Capital. Nat. Social. 2018, 29 (3), 1-8.

6. $\quad$ Watkins, D. J.; Torres Zayas, H. R.; Vélez Vega, C. M.; Rosario, Z.; Welton, M.; Agosto Arroyo, L. D.; Cardona, N.; Díaz Reguero, Z. J.; Santos Rivera, A.; Huerta-Montañez, G.; Brown, P.; Alshawabkeh, A.; Cordero, J. F.; Meeker, J. D., Investigating the impact of Hurricane Maria on an ongoing birth cohort in Puerto Rico. Popul. Environ. 2020, 42 (1), 95-111.

7. Wang, Z.; Liu, Y.; Tao, P.; Shen, Q.; Yi, N.; Zhang, F.; Liu, Q.; Song, C.; Zhang, D.; Shang, W.; Deng, T., Bio-inspired evaporation through plasmonic film of nanoparticles at the airwater interface. Small (Weinheim an der Bergstrasse, Germany) 2014, 10 (16), 3234-3239.

8. Ghasemi, H.; Ni, G.; Marconnet, A. M.; Loomis, J.; Yerci, S.; Miljkovic, N.; Chen, G., Solar steam generation by heat localization. Nat. Commun. 2014, 5, 4449.

9. Liu, H.; Huang, Z.; Liu, K.; Hu, X.; Zhou, J., Interfacial Solar-to-Heat Conversion for Desalination. Adv. Energy Mater. 2019, 9 (21), 1900310.

10. Chang, C.; Yang, C.; Liu, Y.; Tao, P.; Song, C.; Shang, W.; Wu, J.; Deng, T., Efficient Solar-Thermal Energy Harvest Driven by Interfacial Plasmonic Heating-Assisted Evaporation. ACS Appl. Mater. Interfaces 2016, 8 (35), 23412-23418.

11. Wang, Z.; Horseman, T.; Straub, A. P.; Yip, N. Y.; Li, D.; Elimelech, M.; Lin, S., Pathways and challenges for efficient solar-thermal desalination. Science Advances 2019, 5 (7), eaax0763. 
12. Tao, P.; Ni, G.; Song, C.; Shang, W.; Wu, J.; Zhu, J.; Chen, G.; Deng, T., Solar-driven interfacial evaporation. Nat Energy 2018, 3 (12), 1031-1041.

13. Zeng, Y.; Yao, J.; Horri, B. A.; Wang, K.; Wu, Y.; Li, D.; Wang, H., Solar evaporation enhancement using floating light-absorbing magnetic particles. Energy \& Environmental Science 2011, 4 (10), 4074-4078.

14. Zhou, L.; Tan, Y.; Wang, J.; Xu, W.; Yuan, Y.; Cai, W.; Zhu, S.; Zhu, J., 3D self-assembly of aluminium nanoparticles for plasmon-enhanced solar desalination. Nat. Photonics 2016, 10, 393-398.

15. Jia, C.; Li, Y.; Yang, Z.; Chen, G.; Yao, Y.; Jiang, F.; Kuang, Y.; Pastel, G.; Xie, H.; Yang, B.; Das, S.; Hu, L., Rich Mesostructures Derived from Natural Woods for Solar Steam Generation. Joule 2017, 1 (3), 588-599.

16. Hu, X.; Xu, W.; Zhou, L.; Tan, Y.; Wang, Y.; Zhu, S.; Zhu, J., Tailoring Graphene OxideBased Aerogels for Efficient Solar Steam Generation under One Sun. Adv Mater 2017, 29 (5), 1604031.

17. Li, X.; Xu, W.; Tang, M.; Zhou, L.; Zhu, B.; Zhu, S.; Zhu, J., Graphene oxide-based efficient and scalable solar desalination under one sun with a confined 2D water path. Proceedings of the National Academy of Sciences 2016, 113 (49), 13953-13958.

18. Tao, F.; Zhang, Y.; Cao, S.; Yin, K.; Chang, X.; Lei, Y.; Fan, R.; Dong, L.; Yin, Y.; Chen, $\mathrm{X}$., CuS nanoflowers/semipermeable collodion membrane composite for high-efficiency solar vapor generation. Materials Today Energy 2018, 9, 285-294.

19. Shang, M.; Li, N.; Zhang, S.; Zhao, T.; Zhang, C.; Liu, C.; Li, H.; Wang, Z., FullSpectrum Solar-to-Heat Conversion Membrane with Interfacial Plasmonic Heating Ability for High-Efficiency Desalination of Seawater. ACS Applied Energy Materials 2018, 1 (1), 56-61.

20. Zhang, L.; Tang, B.; Wu, J.; Li, R.; Wang, P., Hydrophobic Light-to-Heat Conversion Membranes with Self-Healing Ability for Interfacial Solar Heating. Adv. Mater. 2015, 27 (33), 4889-4894.

21. Ni, G.; Zandavi, S. H.; Javid, S. M.; Boriskina, S. V.; Cooper, T. A.; Chen, G., A saltrejecting floating solar still for low-cost desalination. Energy \& Environmental Science 2018, 11 (6), 1510-1519. 
22. Wilson, H. M.; Tushar; Raheman Ar, S.; Jha, N., Plant-derived carbon nanospheres for high efficiency solar-driven steam generation and seawater desalination at low solar intensities. Solar Energy Materials and Solar Cells 2020, 210, 110489.

23. Politano, A.; Argurio, P.; Di Profio, G.; Sanna, V.; Cupolillo, A.; Chakraborty, S.; Arafat, H. A.; Curcio, E., Photothermal Membrane Distillation for Seawater Desalination. Adv Mater 2017, 29 (2).

24. Dongare, P. D.; Alabastri, A.; Pedersen, S.; Zodrow, K. R.; Hogan, N. J.; Neumann, O.; Wu, J. J.; Wang, T. X.; Deshmukh, A.; Elimelech, M.; Li, Q. L.; Nordlander, P.; Halas, N. J., Nanophotonics-enabled solar membrane distillation for off-grid water purification. P Natl Acad Sci USA 2017, 114 (27), 6936-6941.

25. Cheng, L.-H.; Lin, Y.-H.; Chen, J., Enhanced air gap membrane desalination by novel finned tubular membrane modules. J Membrane Sci 2011, 378 (1), 398-406.

26. Wu, X.; Cao, S.; Ghim, D.; Jiang, Q.; Singamaneni, S.; Jun, Y.-S., A thermally engineered polydopamine and bacterial nanocellulose bilayer membrane for photothermal membrane distillation with bactericidal capability. Nano Energy 2021, 79, 105353.

27. Chiavazzo, E.; Morciano, M.; Viglino, F.; Fasano, M.; Asinari, P., Passive solar highyield seawater desalination by modular and low-cost distillation. Nat Sustain 2018, 1 (12), 763 772.

28. Xu, Z.; Zhang, L.; Zhao, L.; Li, B.; Bhatia, B.; Wang, C.; Wilke, K. L.; Song, Y.; Labban, O.; Lienhard, J. H.; Wang, R.; Wang, E. N., Ultrahigh-efficiency desalination via a thermallylocalized multistage solar still. Energy \& Environmental Science 2020, 13 (3), 830-839.

29. Singh, S. C.; ElKabbash, M.; Li, Z.; Li, X.; Regmi, B.; Madsen, M.; Jalil, S. A.; Zhan, Z.; Zhang, J.; Guo, C., Solar-trackable super-wicking black metal panel for photothermal water sanitation. Nat Sustain 2020, 3 (11), 938-946.

30. Benghanem, M., Optimization of tilt angle for solar panel: Case study for Madinah, Saudi Arabia. Applied Energy 2011, 88 (4), 1427-1433.

31. Kirkham, M. B., 3 - Structure and Properties of Water. In Principles of Soil and Plant Water Relations, 2nd ed.; Kirkham, M. B., Ed. Academic Press: Burlington, 2005; pp 27-40.

32. Walton, N. R. G., Electrical Conductivity and Total Dissolved Solids-What is Their Precise Relationship? Desalination 1989, 72 (3), 275-292. 
33. Nayar, K. G.; Sharqawy, M. H.; Banchik, L. D.; Lienhard V, J. H., Thermophysical properties of seawater: A review and new correlations that include pressure dependence. Desalination 2016, 390, 1-24.

34. Jacob, P.; Zhang, T.; Laborie, S.; Cabassud, C., Influence of operating conditions on wetting and wettability in membrane distillation using Detection of Dissolved Tracer Intrusion (DDTI). Desalination 2019, 468, 114086.

35. Rezaei, M.; Warsinger, D. M.; Lienhard V, J. H.; Duke, M. C.; Matsuura, T.; Samhaber, W. M., Wetting phenomena in membrane distillation: Mechanisms, reversal, and prevention. Water Res 2018, 139, 329-352.

36. Tijing, L. D.; Woo, Y. C.; Choi, J.-S.; Lee, S.; Kim, S.-H.; Shon, H. K., Fouling and its control in membrane distillation-A review. J Membrane Sci 2015, 475, 215-244.

37. McDonough, K.; Casteel, K.; Itrich, N.; Menzies, J.; Belanger, S.; Wehmeyer, K.; Federle, T., Evaluation of anionic surfactant concentrations in US effluents and probabilistic determination of their combined ecological risk in mixing zones. Sci Total Environ 2016, 572, 434-441.

38. Liwarska-Bizukojc, E.; Bizukojc, M., Digital image analysis to estimate the influence of sodium dodecyl sulphate on activated sludge flocs. Process Biochemistry 2005, 40 (6), 2067-2072.

39. Chew, N. G. P.; Zhao, S.; Loh, C. H.; Permogorov, N.; Wang, R., Surfactant effects on water recovery from produced water via direct-contact membrane distillation. J. Membr. Sci. 2017, $528,126-134$.

40. Gleick, P. H., Basic Water Requirements for Human Activities: Meeting Basic Needs. Water International 1996, 21 (2), 83-92.

41. Guan, G.; Lou, H.; Yao, C.; Li, J.; Yang, X., Achieving sustainable operation for hypersaline membrane distillation applications: A novel strategy based on the critical Reynolds number. Desalination 2021, 499, 114833.

42. Chen, T. C.; Ho, C. D., Immediate assisted solar direct contact membrane distillation in saline water desalination. J Membrane Sci 2010, 358 (1-2), 122-130.

43. Allen, M. J.; Edberg, S. C.; Reasoner, D. J., Heterotrophic plate count bacteria-what is their significance in drinking water? Int. J. Food Microbiol. 2004, 92 (3), 265-274. 


\section{Supporting Information}

\section{Passive Permeate-Side-Heated Solar Thermal Membrane Distillation: Extracting Potable Water from Seawater, Surface Water, and Municipal Wastewater at High Single- Stage Solar Efficiencies}

Rahamat Ullah Tanvir ${ }^{a}{ }^{\dagger}$, Shahin Ahmed Sujon ${ }^{a}$, and Peng $\mathrm{Yi}^{\mathrm{a}}{ }^{\mathrm{a}}$ *

a Department of Civil, Environmental and Geomatics Engineering,

Florida Atlantic University, Boca Raton, Florida 33431, USA

${ }^{\dagger}$ Current Address: Department of Civil and Environmental Engineering, University of Missouri, Columbia, Missouri 65211, USA

* Corresponding author: Peng Yi, Email: pyi@fau.edu, Phone: 561-297-2808.

7 Figures (Figure S1 to S7)

2 Tables (Table S1 to S2) 


\section{Contents}

Figure S1. Scanning Electron Microscopy (SEM) images of the surface of an unmodified (a, b, c) and a carbon black NPs-coated (d, e, f) $0.45 \mu \mathrm{m}$ PVDF membrane. Cross-sectional SEM images of $(\mathrm{g})$ the unmodified membrane and $(\mathrm{h})$ the membrane coated with carbon-black NPs on the top. The surface density of carbon black NPs was $3.31 \mathrm{~g} / \mathrm{m}^{2}$.

Figure S2. Evaporation flux of DI water under the simulated sunlight at an irradiance of 2000 $\mathrm{W} / \mathrm{m}^{2}$ when the water was covered with PVDF membranes. The permeate side of membranes were coated with different surface densities of carbon black NPs. There was no significant change in evaporation flux $\left[2.65-3.02 \mathrm{~kg} /\left(\mathrm{m}^{2} \cdot \mathrm{h}\right)\right]$ when the surface density of carbon black NPs was within $3.69-10.6 \mathrm{~g} / \mathrm{m}^{2}$.

Figure S3. Irradiance variation of natural sunlight during the daytime of the (a) rainy day in August, (b) cloudy day in September, (c) sunny winter in January, and (d) sunny day in July on which the 24-hour long distillate production experiments shown in Figure $3 \mathrm{~b}$ were performed.

Figure S4. (a) The distillate production rates of the permeate-side-heated MD system per unit area of solar heat absorber (i.e., the black membrane) during the duplicate 24-hour experiments in different weather conditions. The irradiance variation of natural sunlight during the (b) rainy, (c) cloudy, and (d) sunny days. DI water was used as the feed water, and the inclination of the device was $30^{\circ}$. The location of experiments was on the Boca Raton campus of Florida Atlantic University, $\left(26^{\circ} 22^{\prime} 22.296^{\prime \prime} \mathrm{N}\right.$ and $\left.80^{\circ} 6^{\prime} 11.5812^{\prime \prime} \mathrm{W}\right)$. The average temperature of the rainy (May 31, 2018), cloudy (June 5, 2018), and sunny days (September 18, 2018) were $27^{\circ} \mathrm{C}, 29^{\circ} \mathrm{C}$, and 29 ${ }^{\circ} \mathrm{C}$, respectively.

Figure S5. Photographs of the feed side of (a) unmodified PVDF membrane and the PVDF membranes after long-term experiments with (b) seawater for 41 days, (c) canal water for 22 days, and (d) wastewater for 11 days. All experiments were done 8 hours a day for consecutive days under the simulated sunlight at an irradiance of $1800 \mathrm{~W} / \mathrm{m}^{2}$.

Figure S6. The duplicate long-term experimental results. (a) Distillate production rate per unit area of solar heat absorber (i.e., the black membrane), (b) turbidity, (c) electrical conductivity, (d) chemical oxygen demand, and (e) $\mathrm{pH}$ of the distilled water extracted from seawater (circles), canal 
water (triangles), and municipal wastewater (squares) during the duplicate set of long-term experiments. The system operated 8 hours a day under the simulated sunlight $\left(1800 \mathrm{~W} / \mathrm{m}^{2}\right)$ for 23 , 13, and 8 days with seawater, canal water, and municipal wastewater as the feed water, respectively.

Figure S7. Calibration curve of Signstek Solar Power Irradiance Meter (TES 1333) by LP02-LI19 Pyranometer under natural sunlight. The experiment was conducted from 8 AM to 8 PM on July 14, 2020 on the Boca Raton campus of Florida Atlantic University, (26 22' 22.296" N and 80 6' $\left.11.5812^{\prime \prime} \mathrm{W}\right)$.

Table S1. Water quality report of distilled water by National Testing Laboratories, Ltd. (Cleveland, Ohio, United States). The distilled water was accumulated throughout the entire period of long-term experiments shown in Figures $5 \mathrm{~b}-\mathrm{f}$ and stored in a refrigerator at $3{ }^{\circ} \mathrm{C}$ before sending for tests. The distilled water extracted from all types of feed water meets the United States National Primary and Secondary Drinking Water Regulations for total coliform and E. coli, 22 heavy metals and minerals, seven anions, five physical factors, four trihalomethanes, and 47 volatile organic compounds except for dichloromethane.

Table S2. The quality of two batches of seawater, canal water, and municipal wastewater used as the feed water for long-term experiments under the simulated sunlight. The Figure 4d-f reported the average and standard deviation of the quality of the two batches of feed water. 

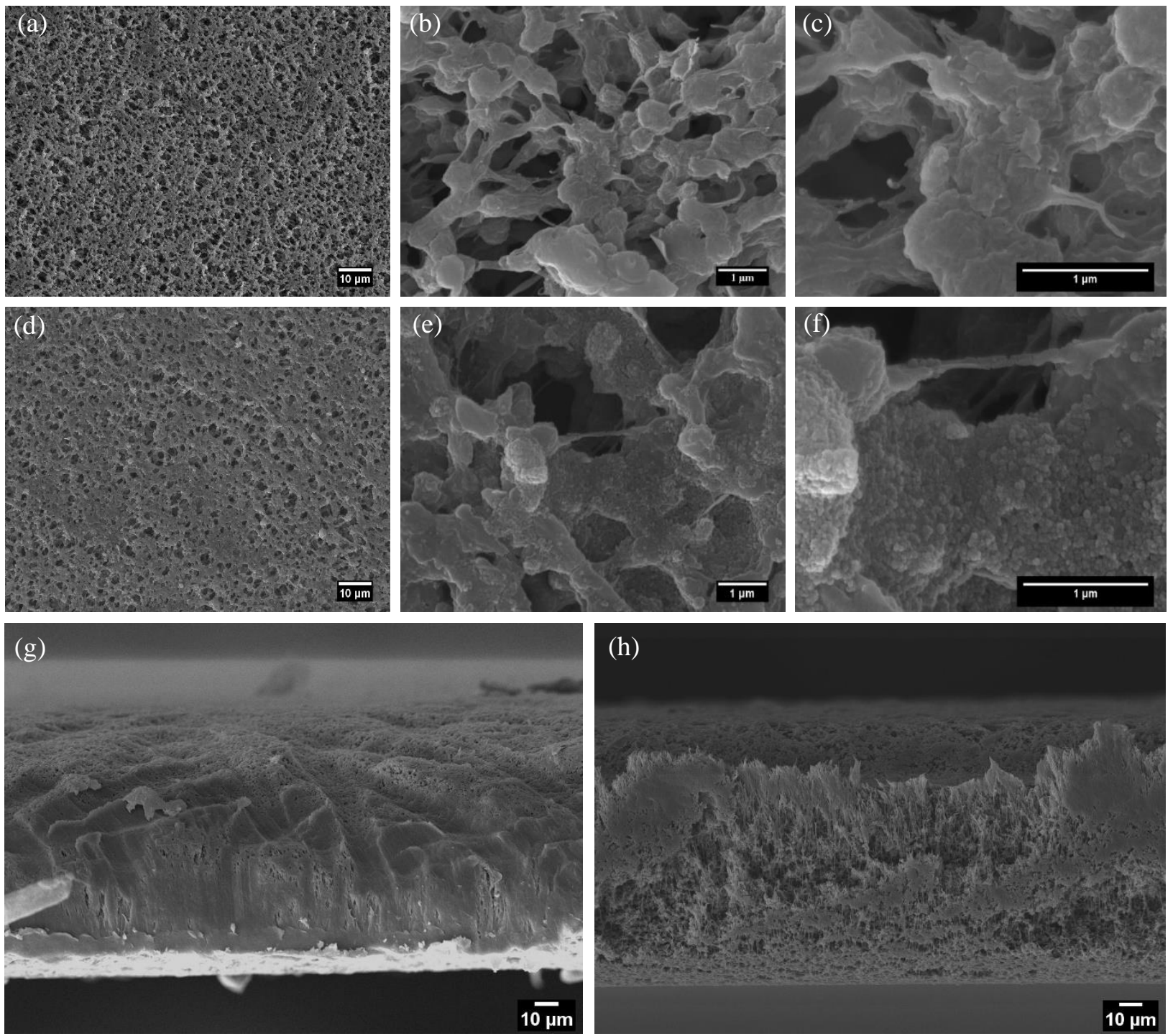

Figure S1. Scanning Electron Microscopy (SEM) images of the surface of an unmodified (a, b, c) and a carbon black NPs-coated (d, e, f) $0.45 \mu \mathrm{m}$ PVDF membrane. Cross-sectional SEM images of $(\mathrm{g})$ the unmodified membrane and $(\mathrm{h})$ the membrane coated with carbon-black NPs on the top. The surface density of carbon black NPs was $3.31 \mathrm{~g} / \mathrm{m}^{2}$. 


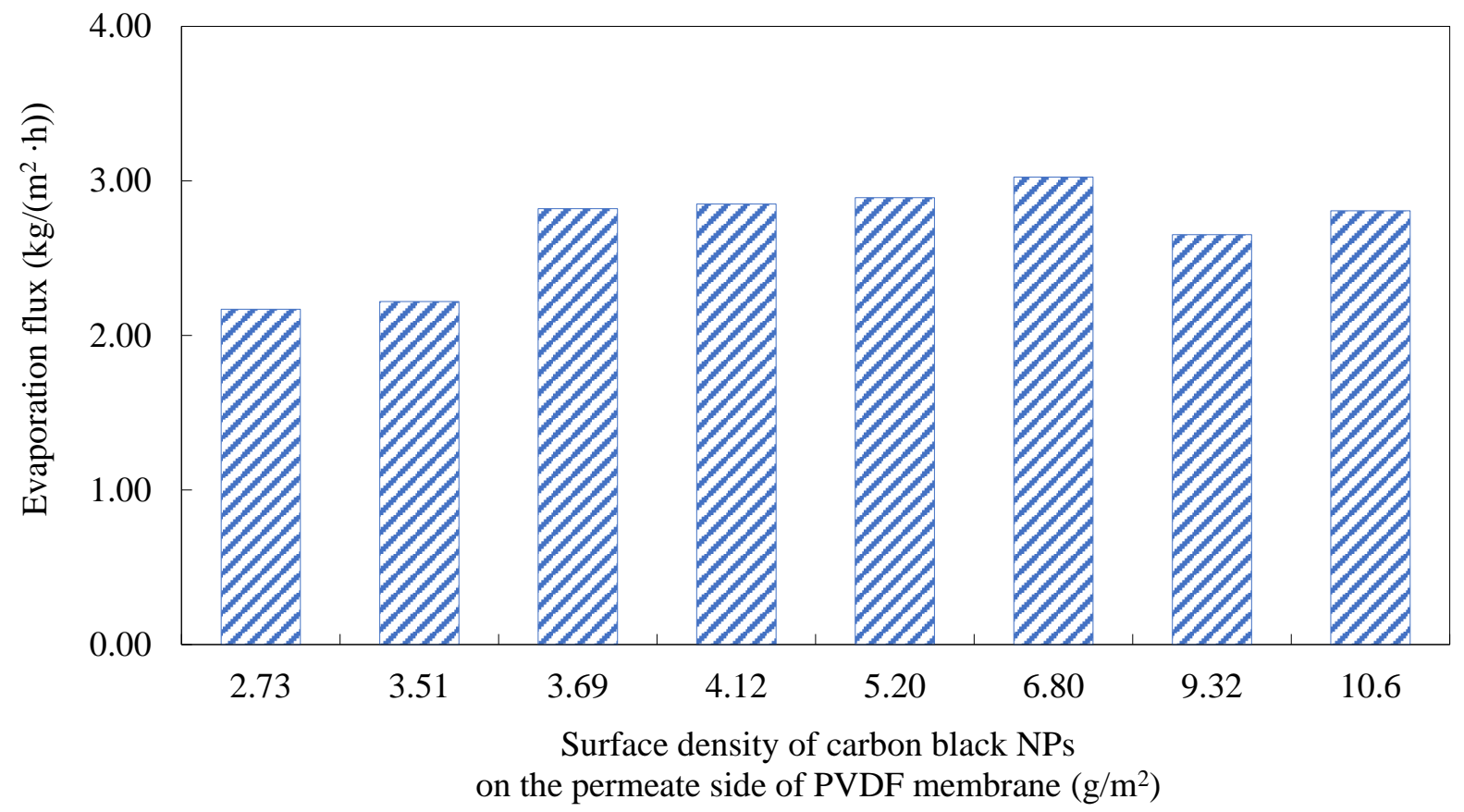

Figure S2. Evaporation flux of DI water under the simulated sunlight at an irradiance of 2000 $\mathrm{W} / \mathrm{m}^{2}$ when the water was covered with PVDF membranes. The permeate side of membranes were coated with different surface densities of carbon black NPs. There was no significant change in evaporation flux $\left[2.65-3.02 \mathrm{~kg} /\left(\mathrm{m}^{2} \cdot \mathrm{h}\right)\right]$ when the surface density of carbon black NPs was within $3.69-10.6 \mathrm{~g} / \mathrm{m}^{2}$. 

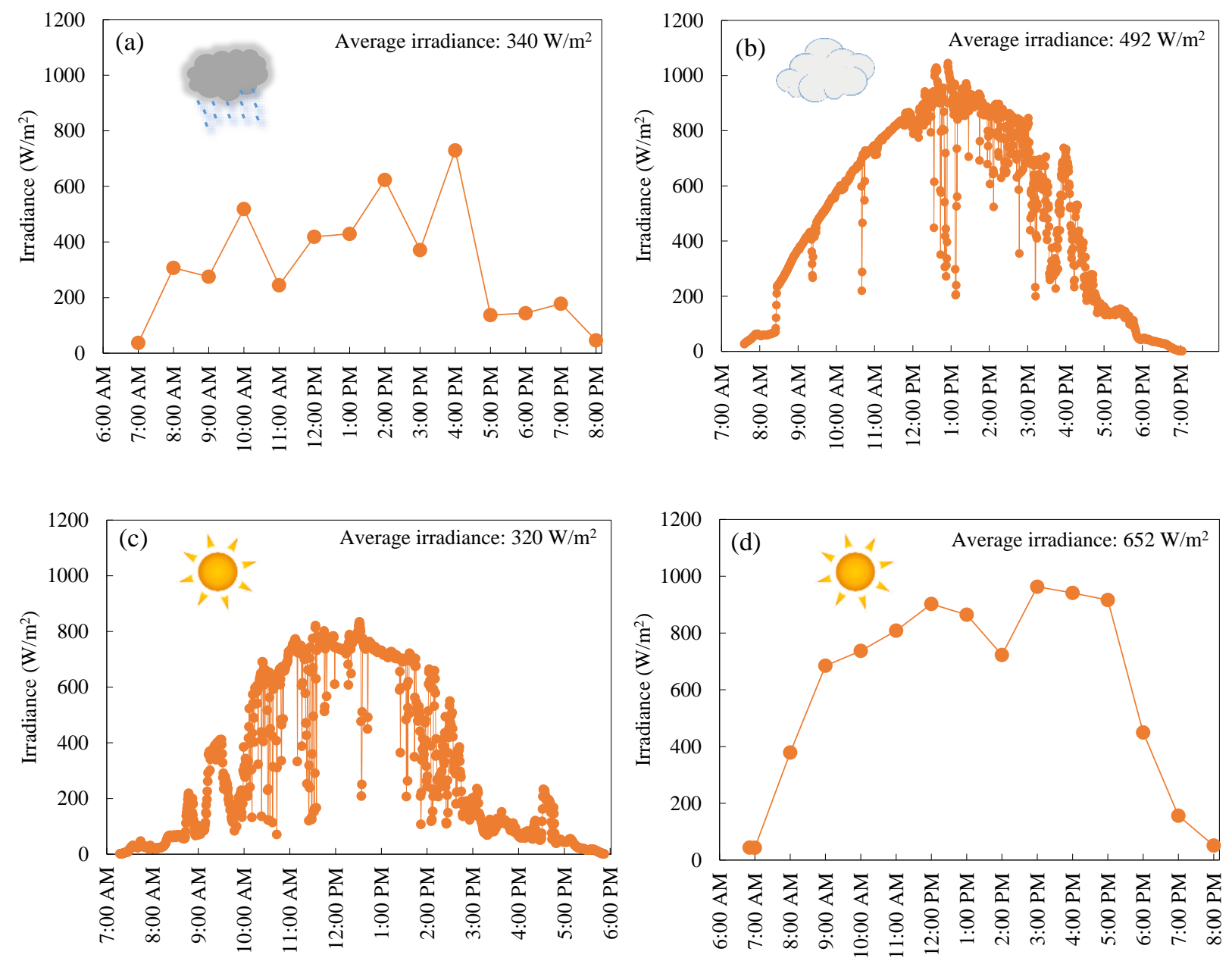

Figure S3. Irradiance variation of natural sunlight during the daytime of the (a) rainy day in August, (b) cloudy day in September, (c) sunny day in January, and (d) sunny day in July on which the 24-hour long distillate production experiments shown in Figure $3 \mathrm{~b}$ were performed. Timeweighted average of daytime irradiances are reported. 

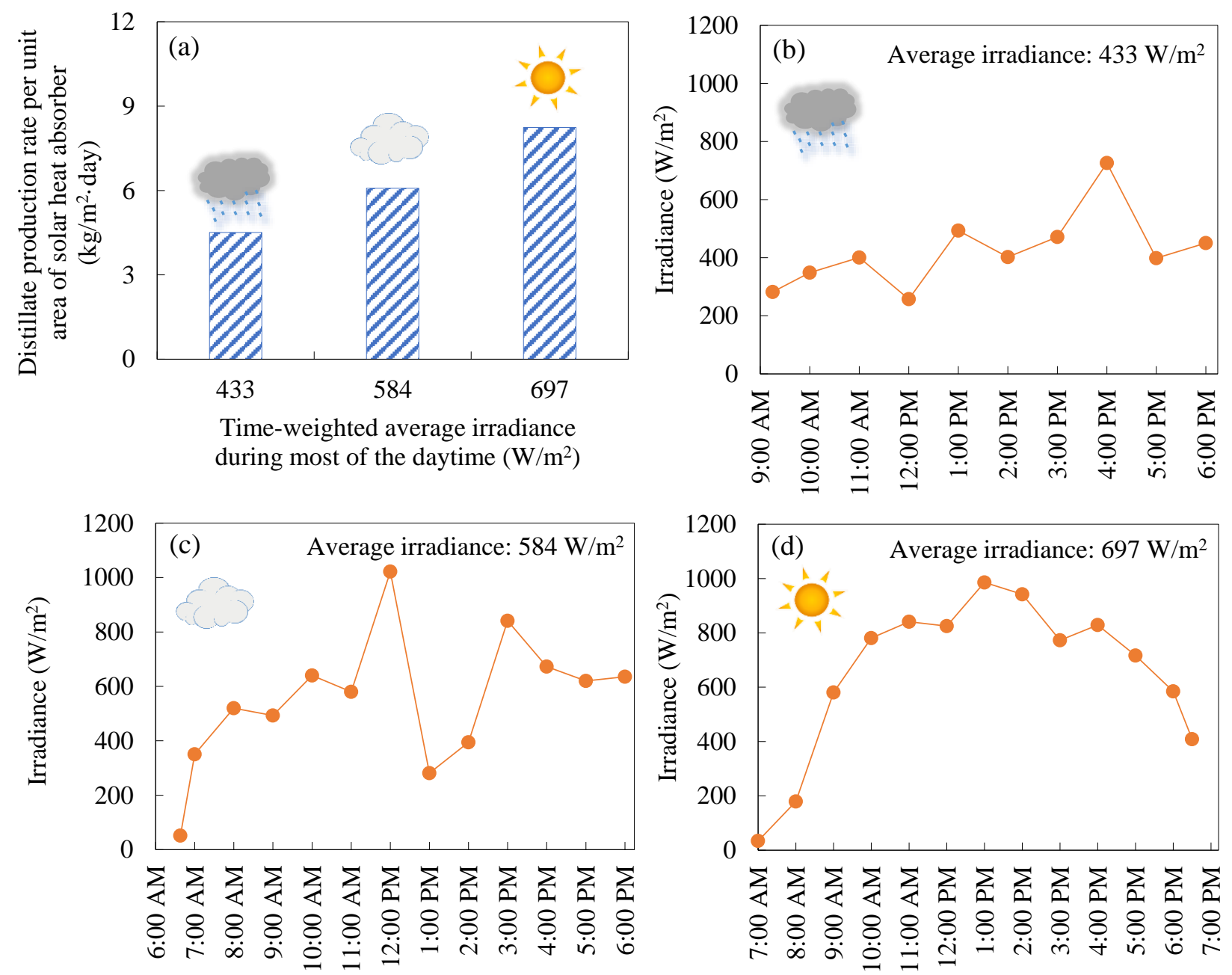

Figure S4. (a) The distillate production rates of the permeate-side-heated MD system per unit area of solar heat absorber (i.e., the black membrane) during the duplicate 24-hour experiments in different weather conditions. The irradiance variation of natural sunlight during the (b) rainy, (c) cloudy, and (d) sunny days. DI water was used as the feed water, and the inclination of the device was $30^{\circ}$. The location of experiments was on the Boca Raton campus of Florida Atlantic University, $\left(26^{\circ} 22^{\prime} 22.296^{\prime \prime} \mathrm{N}\right.$ and $\left.80^{\circ} 6^{\prime} 11.5812^{\prime \prime} \mathrm{W}\right)$. The average temperature of the rainy (May 31, 2018), cloudy (June 5, 2018), and sunny day (September 18, 2018) were $27^{\circ} \mathrm{C}, 29^{\circ} \mathrm{C}$, and 29 ${ }^{\circ} \mathrm{C}$, respectively. Time-weighted average of irradiances are reported. 


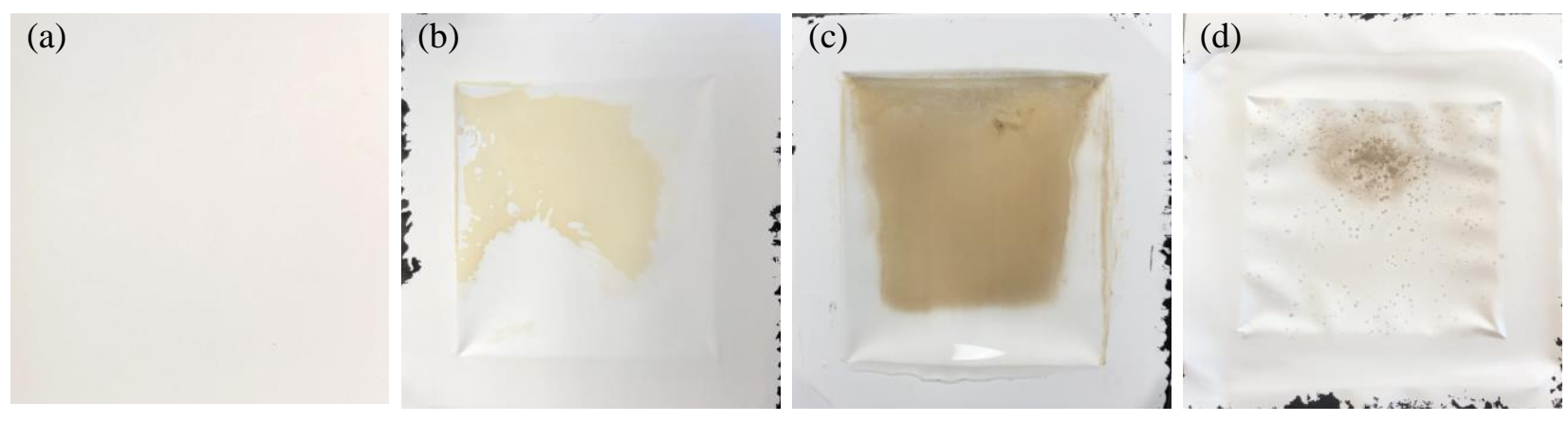

Figure S5. Photographs of the feed side of (a) unmodified PVDF membrane and the PVDF membranes after long-term experiments with (b) seawater for 41 days, (c) canal water for 22 days, and (d) wastewater for 11 days. All experiments were done 8 hours a day for consecutive days under the simulated sunlight at an irradiance of $1800 \mathrm{~W} / \mathrm{m}^{2}$. 

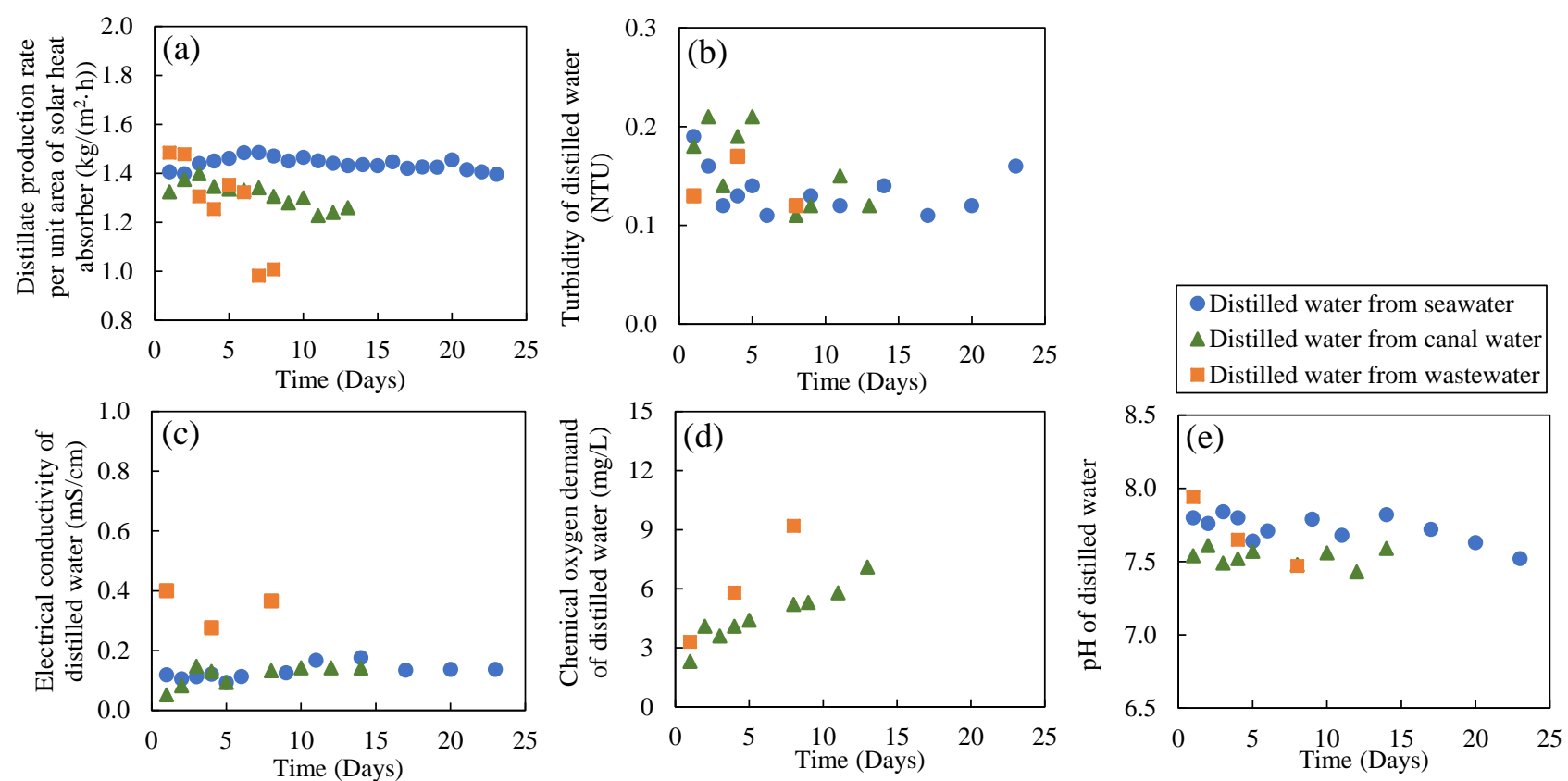

Figure S6. The duplicate long-term experimental results. (a) Distillate production rate per unit area of solar heat absorber (i.e., the black membrane), (b) turbidity, (c) electrical conductivity, (d) chemical oxygen demand, and (e) $\mathrm{pH}$ of the distilled water extracted from seawater (circles), canal water (triangles), and municipal wastewater (squares) during the duplicate set of long-term experiments. The system operated 8 hours a day under the simulated sunlight $\left(1800 \mathrm{~W} / \mathrm{m}^{2}\right)$ for 23 , 13, and 8 days with seawater, canal water, and municipal wastewater as the feed water, respectively. 


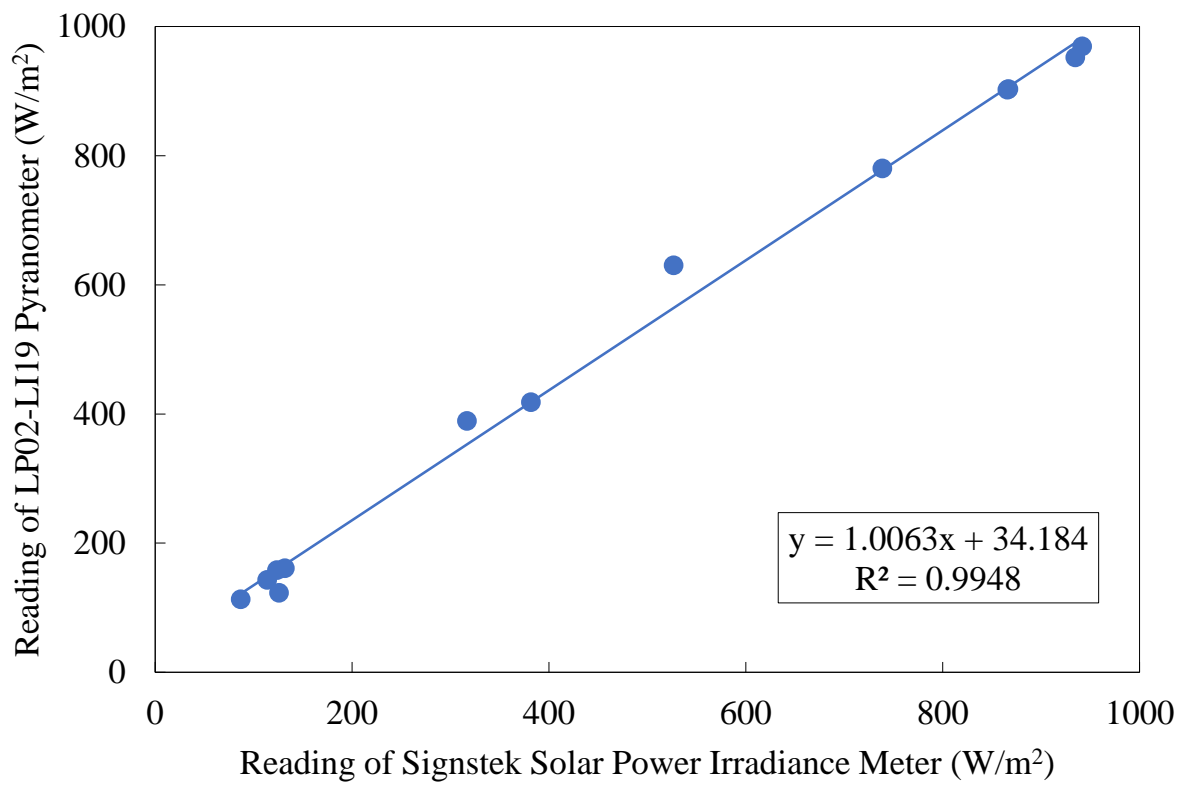

Figure S7. Calibration curve of Signstek Solar Power Irradiance Meter (TES 1333) by LP02-LI19 Pyranometer under natural sunlight. The experiment was conducted from 8 AM to 8 PM on July 14, 2020 on the Boca Raton campus of Florida Atlantic University, (26 $22^{\prime} 22.296^{\prime \prime} \mathrm{N}$ and $80^{\circ} 6^{\prime}$ $\left.11.5812^{\mathrm{N}} \mathrm{W}\right)$. 
Table S1. Water quality report of distilled water by National Testing Laboratories, Ltd. (Cleveland, Ohio, United States). The distilled water was accumulated throughout the entire period of long-term experiments shown in Figures $5 \mathrm{~b}$-f and stored in a refrigerator at $3{ }^{\circ} \mathrm{C}$ before sending for tests. The distilled water extracted from all types of feed water meets the United States National Primary and Secondary Drinking Water Regulations for total coliform and E. coli, 22 heavy metals and minerals, seven anions, five physical factors, four trihalomethanes, and 47 volatile organic compounds except for dichloromethane.

\begin{tabular}{|c|c|c|c|c|c|}
\hline \multicolumn{6}{|c|}{ Microbiological } \\
\hline \multicolumn{6}{|c|}{ Total Coliform and E. coli were ABSENT for ALL types of distilled water } \\
\hline \multicolumn{6}{|c|}{ Inorganic Analytes - Metals } \\
\hline Contaminant & Unit & $\begin{array}{l}\text { National } \\
\text { standards }\end{array}$ & $\begin{array}{l}\text { Distilled water } \\
\text { from seawater }\end{array}$ & $\begin{array}{l}\text { Distilled water } \\
\text { from canal water }\end{array}$ & $\begin{array}{l}\text { Distilled water } \\
\text { from wastewater }\end{array}$ \\
\hline Aluminum & $\mathrm{mg} / \mathrm{L}$ & $\begin{array}{c}0.05- \\
0.20 \\
\end{array}$ & ND & ND & ND \\
\hline Arsenic & $\mathrm{mg} / \mathrm{L}$ & 0.01 & ND & ND & ND \\
\hline Barium & $\mathrm{mg} / \mathrm{L}$ & 2.00 & ND & ND & ND \\
\hline Cadmium & $\mathrm{mg} / \mathrm{L}$ & 0.005 & ND & ND & ND \\
\hline Calcium & $\mathrm{mg} / \mathrm{L}$ & - & 6.2 & 6.4 & ND \\
\hline Chromium & $\mathrm{mg} / \mathrm{L}$ & 0.10 & ND & ND & ND \\
\hline Copper & $\mathrm{mg} / \mathrm{L}$ & 1.30 & ND & ND & ND \\
\hline Iron & $\mathrm{mg} / \mathrm{L}$ & 0.30 & ND & ND & ND \\
\hline Lead & $\mathrm{mg} / \mathrm{L}$ & 0.015 & ND & ND & ND \\
\hline Lithium & $\mathrm{mg} / \mathrm{L}$ & - & 0.003 & 0.003 & ND \\
\hline Magnesium & $\mathrm{mg} / \mathrm{L}$ & - & 0.12 & 0.12 & ND \\
\hline Manganese & $\mathrm{mg} / \mathrm{L}$ & 0.05 & ND & ND & ND \\
\hline Mercury & $\mathrm{mg} / \mathrm{L}$ & 0.002 & ND & ND & ND \\
\hline Nickel & $\mathrm{mg} / \mathrm{L}$ & - & ND & ND & ND \\
\hline Potassium & $\mathrm{mg} / \mathrm{L}$ & - & ND & ND & ND \\
\hline Selenium & $\mathrm{mg} / \mathrm{L}$ & 0.05 & ND & ND & ND \\
\hline Silica & $\mathrm{mg} / \mathrm{L}$ & - & 4.4 & 5 & 0.80 \\
\hline Silver & $\mathrm{mg} / \mathrm{L}$ & 0.10 & ND & ND & ND \\
\hline Sodium & $\mathrm{mg} / \mathrm{L}$ & - & 3 & 3 & ND \\
\hline Strontium & $\mathrm{mg} / \mathrm{L}$ & - & 0.002 & 0.003 & 0.002 \\
\hline Uranium & $\mathrm{mg} / \mathrm{L}$ & 0.03 & ND & ND & ND \\
\hline Zinc & $\mathrm{mg} / \mathrm{L}$ & 5.00 & ND & ND & ND \\
\hline \multicolumn{6}{|c|}{ Physical Factors } \\
\hline Total Alkalinity (as $\mathrm{CaCO}_{3}$ ) & $\mathrm{mg} / \mathrm{L}$ & - & ND & ND & 50 \\
\hline Hardness & $\mathrm{mg} / \mathrm{L}$ & - & 16 & 17 & ND \\
\hline $\mathrm{pH}$ & - & $6.5-8.5$ & 6.9 & 7.0 & 7.4 \\
\hline Total dissolved solids & $\mathrm{mg} / \mathrm{L}$ & 500 & 21 & 22 & 31 \\
\hline Turbidity & NTU & $0.30-1$ & 0.10 & 0.30 & 0.70 \\
\hline \multicolumn{6}{|c|}{ Inorganic Analytes - Others } \\
\hline Bromide & $\mathrm{mg} / \mathrm{L}$ & - & ND & ND & ND \\
\hline Chloride & $\mathrm{mg} / \mathrm{L}$ & 250 & 6.7 & 7.4 & ND \\
\hline Fluoride & $\mathrm{mg} / \mathrm{L}$ & 2.0 & ND & ND & ND \\
\hline Nitrate as $\mathrm{N}$ & $\mathrm{mg} / \mathrm{L}$ & 10 & ND & ND & ND \\
\hline Nitrite as $\mathrm{N}$ & $\mathrm{mg} / \mathrm{L}$ & 1.0 & ND & ND & ND \\
\hline Ortho Phosphate & $\mathrm{mg} / \mathrm{L}$ & - & ND & ND & ND \\
\hline
\end{tabular}




\begin{tabular}{|c|c|c|c|c|c|}
\hline Sulfate & $\mathrm{mg} / \mathrm{L}$ & 250 & ND & ND & ND \\
\hline \multicolumn{6}{|c|}{ Organic Analytes - Trihalomethanes } \\
\hline Bromodichloromethane & $\mathrm{mg} / \mathrm{L}$ & - & ND & ND & ND \\
\hline Bromoform & $\mathrm{mg} / \mathrm{L}$ & - & ND & ND & ND \\
\hline Chloroform & $\mathrm{mg} / \mathrm{L}$ & - & ND & ND & ND \\
\hline Dibromochloromethane & $\mathrm{mg} / \mathrm{L}$ & - & ND & ND & ND \\
\hline $\begin{array}{l}\text { Total Trihalomethanes } \\
\text { (TTHMs) }\end{array}$ & $\mathrm{mg} / \mathrm{L}$ & 0.080 & ND & ND & ND \\
\hline \multicolumn{6}{|c|}{ Organic Analytes - Volatiles } \\
\hline 1,1,1,2-Tetrachloroethane & $\mathrm{mg} / \mathrm{L}$ & - & ND & ND & ND \\
\hline 1,1,1-Trichloroethane & $\mathrm{mg} / \mathrm{L}$ & 0.20 & ND & ND & ND \\
\hline 1,1,2,2-Tetrachloroethane & $\mathrm{mg} / \mathrm{L}$ & - & ND & ND & ND \\
\hline 1,1,2-Trichloroethane & $\mathrm{mg} / \mathrm{L}$ & 0.005 & ND & ND & ND \\
\hline 1,1-Dichloroethane & $\mathrm{mg} / \mathrm{L}$ & - & ND & ND & ND \\
\hline 1,1-Dichloroethylene & $\mathrm{mg} / \mathrm{L}$ & 0.007 & ND & ND & ND \\
\hline 1,1-Dichloropropene & $\mathrm{mg} / \mathrm{L}$ & - & ND & ND & ND \\
\hline 1,2,3-Trichlorobenzene & $\mathrm{mg} / \mathrm{L}$ & - & ND & ND & ND \\
\hline 1,2,3-Trichloropropane & $\mathrm{mg} / \mathrm{L}$ & - & ND & ND & ND \\
\hline 1,2,4-Trichlorobenzene & $\mathrm{mg} / \mathrm{L}$ & 0.07 & $\mathrm{ND}$ & ND & ND \\
\hline 1,2-Dichlorobenzene & $\mathrm{mg} / \mathrm{L}$ & 0.60 & ND & ND & ND \\
\hline 1,2-Dichloroethane & $\mathrm{mg} / \mathrm{L}$ & 0.005 & ND & ND & ND \\
\hline 1,2-Dichloropropane & $\mathrm{mg} / \mathrm{L}$ & 0.005 & ND & ND & ND \\
\hline 1,3-Dichlorobenzene & $\mathrm{mg} / \mathrm{L}$ & - & ND & ND & ND \\
\hline 1,3-Dichloropropane & $\mathrm{mg} / \mathrm{L}$ & - & ND & ND & ND \\
\hline 1,4-Dichlorobenzene & $\mathrm{mg} / \mathrm{L}$ & 0.075 & ND & ND & ND \\
\hline 2,2-Dichloropropane & $\mathrm{mg} / \mathrm{L}$ & - & ND & ND & ND \\
\hline 2-Chlorotoluene & $\mathrm{mg} / \mathrm{L}$ & - & ND & ND & ND \\
\hline 4-Chlorotoluene & $\mathrm{mg} / \mathrm{L}$ & - & ND & ND & ND \\
\hline Acetone & $\mathrm{mg} / \mathrm{L}$ & - & 0.13 & 0.02 & 0.91 \\
\hline Benzene & $\mathrm{mg} / \mathrm{L}$ & 0.005 & ND & ND & ND \\
\hline Bromobenzene & $\mathrm{mg} / \mathrm{L}$ & - & ND & ND & ND \\
\hline Bromomethane & $\mathrm{mg} / \mathrm{L}$ & - & ND & ND & ND \\
\hline Carbon Tetrachloride & $\mathrm{mg} / \mathrm{L}$ & 0.005 & ND & ND & ND \\
\hline Chlorobenzene & $\mathrm{mg} / \mathrm{L}$ & 0.10 & ND & ND & ND \\
\hline Chloroethane & $\mathrm{mg} / \mathrm{L}$ & - & ND & ND & ND \\
\hline Chloromethane & $\mathrm{mg} / \mathrm{L}$ & - & ND & ND & ND \\
\hline cis-1,2-Dichloroethylene & $\mathrm{mg} / \mathrm{L}$ & 0.07 & ND & ND & ND \\
\hline cis-1,3-Dichloropropene & $\mathrm{mg} / \mathrm{L}$ & - & ND & ND & ND \\
\hline $\begin{array}{l}\text { Dibromochloropropane } \\
\text { (DBCP) }\end{array}$ & $\mathrm{mg} / \mathrm{L}$ & - & ND & ND & ND \\
\hline Dibromomethane & $\mathrm{mg} / \mathrm{L}$ & - & ND & ND & ND \\
\hline Dichlorodifluoromethane & $\mathrm{mg} / \mathrm{L}$ & - & ND & ND & ND \\
\hline Dichloromethane & $\mathrm{mg} / \mathrm{L}$ & 0.005 & 0.013 & 0.007 & 0.810 \\
\hline Ethylene dibromide (EDB) & $\mathrm{mg} / \mathrm{L}$ & - & ND & ND & ND \\
\hline Ethylbenzene & $\mathrm{mg} / \mathrm{L}$ & 0.70 & ND & ND & ND \\
\hline Methyl Tert Butyl Ether & $\mathrm{mg} / \mathrm{L}$ & - & ND & ND & ND \\
\hline Methyl-Ethyl Ketone & $\mathrm{mg} / \mathrm{L}$ & - & 0.70 & 0.45 & 3.10 \\
\hline Styrene & $\mathrm{mg} / \mathrm{L}$ & 0.10 & ND & ND & ND \\
\hline Tetrachloroethylene & $\mathrm{mg} / \mathrm{L}$ & 0.005 & ND & ND & ND \\
\hline Tetrahydrofuran & $\mathrm{mg} / \mathrm{L}$ & - & ND & ND & 0.01 \\
\hline Toluene & $\mathrm{mg} / \mathrm{L}$ & 1.0 & ND & ND & ND \\
\hline trans-1,2-Dichloroethylene & $\mathrm{mg} / \mathrm{L}$ & 0.1 & ND & ND & ND \\
\hline trans-1,3-Dichloropropene & $\mathrm{mg} / \mathrm{L}$ & - & ND & ND & ND \\
\hline Trichloroethylene & $\mathrm{mg} / \mathrm{L}$ & 0.005 & ND & ND & ND \\
\hline
\end{tabular}




\begin{tabular}{|l|c|c|c|c|c|}
\hline Trichlorofluoromethane & $\mathrm{mg} / \mathrm{L}$ & - & $\mathrm{ND}$ & $\mathrm{ND}$ & ND \\
\hline Vinyl Chloride & $\mathrm{mg} / \mathrm{L}$ & 0.002 & $\mathrm{ND}$ & $\mathrm{ND}$ & ND \\
\hline Xylenes (Total) & $\mathrm{mg} / \mathrm{L}$ & 10 & $\mathrm{ND}$ & $\mathrm{ND}$ & ND \\
\hline
\end{tabular}

Note: "ND" = Not Detected; “-" = Not regulated by National Primary and Secondary Drinking Water Regulations set by the US Environmental Protection Agency (EPA). 
Table S2. The quality of two batches of seawater, canal water, and municipal wastewater used as the feed water for long-term experiments under the simulated sunlight. The Figure 4d-f reported the average and standard deviation of the quality of the two batches of feed water.

\begin{tabular}{|l|c|c|c|c|c|c|}
\hline \multirow{2}{*}{ Water quality parameters } & \multicolumn{2}{|c|}{ Seawater } & \multicolumn{2}{c|}{ Canal water } & \multicolumn{2}{c|}{ Municipal wastewater } \\
\cline { 2 - 7 } & $\begin{array}{c}\text { Batch for } \\
\text { Figure 5 }\end{array}$ & $\begin{array}{c}\text { Batch for } \\
\text { Figure S6 }\end{array}$ & $\begin{array}{c}\text { Batch for } \\
\text { Figure 5 }\end{array}$ & $\begin{array}{c}\text { Batch for } \\
\text { Figure S6 }\end{array}$ & $\begin{array}{c}\text { Batch for } \\
\text { Figure 5 }\end{array}$ & $\begin{array}{c}\text { Batch for } \\
\text { Figure S6 }\end{array}$ \\
\hline Turbidity (NTU) & 0.62 & 0.64 & 3.16 & 5.26 & 327 & 345 \\
\hline Electrical conductivity (mS/cm) & 51.30 & 53.47 & 0.49 & 23.13 & 0.86 & 0.91 \\
\hline pH & 8.02 & 8.01 & 7.68 & 7.74 & 7.21 & 7.42 \\
\hline $\begin{array}{l}\text { Chemical oxygen demand } \\
\text { (COD) }(\mathrm{mg} / \mathrm{L})\end{array}$ & - & - & 56 & 106 & 941 & 1015 \\
\hline
\end{tabular}

“-”: COD of seawater could not be measured due to the severe interference by $\mathrm{Cl}^{-}$. 